\title{
Larval description of Nodynus leucofasciatus Lewis, 1879 (Coleoptera: Staphylinidae: Apateticinae) with discussion of Staphylinidae chaetotaxy
}

\author{
Описание иичиночных стадий Nodynus leucofasciatus Lewis, 1879 \\ (Coleoptera: Staphylinidae: Apateticinae) с обсуждением \\ хетотаксии Staphylinidae
}

\author{
Artejom A. Zaytsev ${ }^{1}$, Alexandra S. Tokareva ${ }^{2}$ \\ Артём А. Зайџев ${ }^{1}$, Александра С. Токарева ${ }^{2}$
}

\footnotetext{
Moscow State Pedagogical University, Institute of Biology and Chemistry, Department of Zoology and Ecology, Kibaltchicha str. 6, buld. 3, 129164 Moscow, Russia. E-mail: ztema@mail.ru

${ }^{1}$ Московский Педагогический Государственный Университет, институт биологии и химии, кафедра зоологии и экологии, ул. Кибальчича 6, корп. 3, 129164 Москва, Россия.

2 Museum and Institute of Zoology, Laboratory of Systematics, Zoogeography and Ecology of Invertebrates, Wilcza str. 64,00-679 Poland, Warsaw. E-mail: alexan4tok@gmail.com
}

KEY WORDS: Coleoptera, larva, chaetotaxy, Staphylinidae, Apateticinae.

КЛЮЧЕВЫЕСЛОВА: жесткокрылые, личинка, хетотаксия, Staphylinidae, Apateticinae.

ABSTRACT. Larvae of instars I-III of Nodynus leucofasciatus are described, including data on chaetotaxy. The possibility of applying Bousquet and Goulet [1984] nomenclatural system for Staphylinidae is discussed. An attempt to establish homologous chaetome elements among Staphylinidae and Carabidae is performed. Taxonomic position of Apateticinae is briefly discussed.

РЕЗЮМЕ. Приводится описание личинок I-III возраста Nodynus leucofasciatus, включая данные об их хетотаксии. Обсуждается возможность применения номенклатурной системы Буске и Гуле [Bousquet, Goulet, 1984] для Staphylinidae. Произведена попытка выявления гомологичных элементов хетома у Staphylinidae и Carabidae. Кратко обсуждается таксономическое положение Apateticinae.

\section{Introduction}

Apateticinae Fauvel, 1895 is a small subfamily of Staphylinidae, consisting of 2 genera: Apatetica Westwood, 1848 and Nodynus Waterhouse, 1876 with 19 and seven species accordingly [Newton, 2018], described mostly from South Palaearctic and Oriental regions. The single species, Nodynus leucofasciatus, known from Russian Far East [Shavrin, 2008]. The taxonomic position of this group has changed significantly over time. Both genera were originally described as members of Silphidae [Westwood, 1848; Waterhouse, 1876] due to the superficial resemblance of adults, but later assigned to Staphylinidae by Fauvel [1895], who placed them in Piestini as section Apateticae. Subsequently, this group was moved to Oxytelinae [Bernhauer, Schubert, 1910], Piestinae [Kasule, 1966, Newton, 1982a] and finally considered as separate subfamily Apateticinae [Newton, Thayer, 1992]. Lawrence and Newton [1995] placed Apateticinae near Scaphidiinae in their Oxyteline-group. Grebennikov and Newton [2012] noted that Apateticinae may not be as closely related to Oxytelinae as they thought to be and considered Apateticinae (together with Trigonurinae) as basal group of Staphylinidae. In the most comprehensive molecular phylogenetic study so far [McKenna et al, 2015] Apateticinae regarded as a sistergroup of Scaphidiinae and this clade was found as one of the basal lineages of the family. Alternatively, some authors proposed to return Apatetica and Nodynus to Silphidae [Jansson, 1947; Madge, 1979] or even count them as separate family Apateticidae [Hansen, 1997], but these hypothesis were not widely approved. It should be noted, that in most studies, mentioned above, larval features of Apateticinae have not been discussed.

The knowledge of Apateticinae larvae is rather poor. Last instar of Nodynus leucofasciatus Lewis, 1879 was formally described by Fukuda [1959], but the description itself is very short and sketchy. Some larval characters of Nodynus were mentioned in papers of Kasule [1966] and Newton [1982a], mostly based on Fukuda's study. The larva of Apatetica sp. was described by

How to cite this article: Zaytsev A.A., Tokareva A.S. 2021. Larval description of Nodynus leucofasciatus Lewis, 1879 (Coleoptera: Staphylinidae: Apateticinae) with discussion of Staphylinidae chaetotaxy // Russian Entomol. J. Vol.30. No.4. P.482-499. doi: 10.15298/rusentj.30.4.10 
Grebennikov and Newton [2012], and some differences from $N$. leucofasciatus were pointed out (in this paper photos of last-instar larva of $N$. leucofasciatus, provided by the first author, were used). So the first goal of the present study is to provide the detailed description of all three larval instars of $N$. leucofasciatus, which could help in clarifying the taxonomic position of this group.

The second aim of our work is connected with larval chaetotaxy of Staphylinidae and Coleoptera in general. Traditionally, chaetotaxy pattern of staphylinid larvae is described using nomenclatural system proposed by Ashe and Watrous [1984] for Aleocharinae. However, although that system is strictly homology-based, this principle is not often followed in studies outside Aleocharinae, which leads to certain confusion [Solodovnikov, 2007, also see Discussion]. As a result, we made an attempt to apply the system by Bousquet and Goulet [1984], originally proposed for Carabidae, instead. For doing this, first of all it is necessary to establish homologies between carabid and staphylinid chaetome elements, what we try to perform in present study. One of the arguments supporting this approach can be the fact that certain degree of similarity between Staphylinidae and Carabidae larval chaetotaxy has already been pointed out [Kovarik, Passoa, 1993; Makarov,1996].

\section{Material and methods}

Larvae of $N$. leucofasciatus were identified by the association with adults (Figs 1-4). Material examined: 1 first-instar, 2 second-instar and 2 third-instar larvae together with adults: Russia, South Kuril Islands, $\mathrm{Ku}-$ nashir Island, $44^{\circ} 16^{\prime} 31^{\prime \prime} \mathrm{N} 145^{\circ} 56^{\prime} 29^{\prime \prime} \mathrm{E}$, on fermented Betula sap, 4.VII.2008, leg., det. K. Makarov (MSPU).

Habitus photographs were taken with a Canon EOS 40D camera with a MP-E $65 \mathrm{~mm}$ macro lens. Photos of slide mounts were taken with Canon EOS6D camera attached to a Carl Zeiss AXIO Scope.A1microscope. All photos were processed using Helicon Focus 7.0 software. Line drawings were made in CorelDRAW 12. The specimens were preserved in $70 \%$ ethanol or on slides with Faure's Berlese media and are deposited in Moscow Pedagogical State University, Moscow, Russia (MSPU).

The measurements were taken with an ocular-micrometer mounted on a MBS1 (Lomo) stereo microscope. Sclerites nomenclature mostly follows Lawrence [1991]. The nomenclature of the primary setae and pores follows Bousquet and Goulet [1984] with modifications [Makarov, 1996] and compared with those of Ashe and Watrous [1984]. In some cases (e.g. abdominal segment IX and

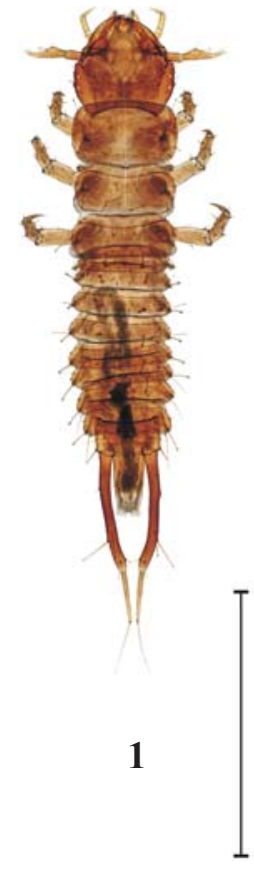

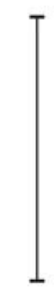

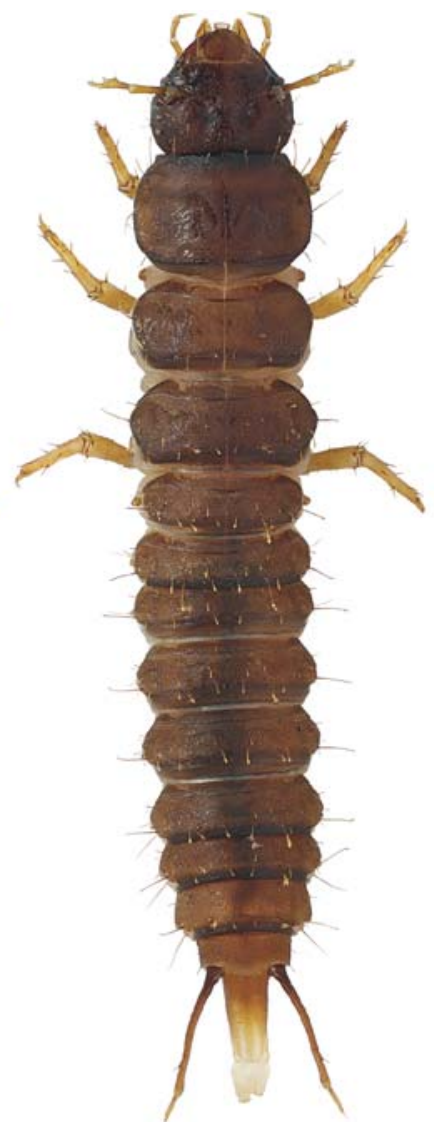

3

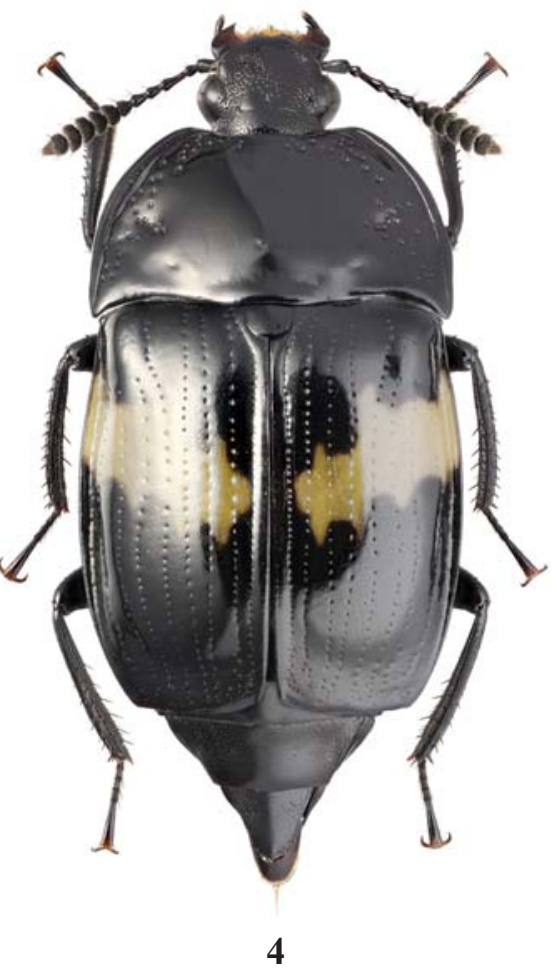

4

Figs 1-4. Nodynus leucofasciatus, habitus, dorsal view: 1 - first-instar larva; 2 - second-instar larva; 3 — third-instar larva; 4 - adult male. Scale bar: $3 \mathrm{~mm}$.

Рис. 1-4. Nodynus leucofasciatus, габитус, сверху: 1- личинка первого возраста; 2 - личинка второго возраста; 3 - личинка третьего возраста; 4 - имаго, самец. Масштаб: 3 мм. 
urogomphi), when setae have not been coded in the original publication, we use data from Thayer's work [2000]. When uncertain in establishing homologies, we use asterix (*) before supposed number. Setae and pores which we fail to homologize are not coded, but their topology is described. Additional setae, which appear in larval instars IIIII and have constant quantity and position, are coded with Greek letters. Secondary setae in larval instars II-III with variable quantity and position are marked with *.

The following abbreviations were used:

1) body sclerites: EM - epimeron, EP - epipleurite, ES - episternum, EU - eusternum, FR - frontal sclerite, HY - hypopleurite, ME - mesonotum, MT - metanotum, PA - parietal sclerite, PR - pronotum, PS - prosternite, ST - sternite, TE - tergite;

2) thoracic apodemes: Aem2-3 - epimeral apodeme (numeric corresponds to segment, on which apodeme is developed), Aes2-3 - episternal apodeme, Ais1-3 - intersegmental apodeme, Apl1-3 - pleural apodeme, F1-3 furca;

3) appendages and their parts: AN - antenna, Sa sensorial appendage, LB - labrum, MN - mandible, Mnt mentum, Pmnt - prementum, Smnt - submentum, Mxa maxillary articulating area, $\mathrm{Ma}$ - mala, Dstcdo - disticardo, Prxcdo - proxicardo, Stp — stipes, Pf — palpifer, CO coxa, TR - trochanter, FE - femur, TT - tibiotarsus, UN uncus, $\mathrm{Cx}$ - coxal cavity;

4) various structures: Asp - atrophied spiracle, Atp anterior tentorial pit, Eb - egg-bursters, Eg - epicranial gland, Es - epicranial suture, Mps - multiporose structure, Hyp.rod - hypopharyngeal rod, Hyp.ch. - hypopharyngeal chitinization area, Hyp.br. - hypopharyngeal bracon, Pp pleuropod, Ptg - pretergal gland, RI-RII - additional hypopharyngeal rods, $\mathrm{Sa}$ - sensorial appendage, $\mathrm{Sp}-$ spiracle, $\mathrm{Tg}$ - tergal gland.

\section{Results and discussion}

\section{First-instar larva}

Figs $1-32$.

Body length (from anterior margin of labrum to the apex of abdominal segment X) $5.6 \mathrm{~mm}$; head length $1.0 \mathrm{~mm}$; head width $1.1 \mathrm{~mm}$, urogomphi length $1.9 \mathrm{~mm}$; maximum width of thorax $1.1 \mathrm{~mm}$; maximum width of abdomen $1.0 \mathrm{~mm}$. Head slightly narrower than prothorax; body elongate, semi-cylindrical; widest across prothorax, then tapering posterad; urogomphi well developed, 2-segmented (Fig. 1).

Head light brown; labrum, antennae and maxilla a bit lighter; mandibles dark brown. Condyle area on parietal sclerite dark brown. Parietal sclerite lighter ventrally, but heavily darkened near ventral epicranial ridge. Thoracic and abdominal tergites dark yellow, anterior carina brown; sternites and pleurites yellow; area of pleural apodems heavily darkened. Thoracic sternites pigmented lighter; ventrites of abdominal segments VIII-IX pigmented heavier. Urogomphi brown; abdominal segment $\mathrm{X}$ brown at the base and yellow on apex. Legs dark yellow, trochanter and claw pigmented heavier. Coxal condyle almost black.

Dorsal surface of head and all body segments except X covered with larger apically frayed or bifurcated setae and smaller simple setae; ventral surfaces membranous, covered mostly with simple setae.
Head (Figs 5-14) prognatous, slightly wider than long. Epicranial suture rather long, about 0.3 as long as head capsule; frontal sutures $\mathrm{v}$-shaped, reaching antennal insertions; their bases contiguous (Fig. 5). Frontoclypeal suture indistinct, slightly defined at lateral margins. Stemmata six on each side (Fig. 6), forming two rows with three stemmata each. Clypeolabral suture distinct; labrum trapezoidal, about 0.4 as long as basal wide; its anterior margin smooth, slightly rounded. Labrum (Fig. 7) with five well sclerotized portions separated by less sclerotized areas; with five setae $\left(* \mathrm{FR}_{8}\right.$ and one medial seta $)$ and single pore $\left({ }^{*} \mathrm{FR}_{\mathrm{g}}\right)$ on each side. Frontal sclerites smooth with honeycomb pattern (Figs 5, $54)$; with eight setae $\left(\mathrm{FR}_{1-6}, * \mathrm{FR}_{7}\right.$ and seta located between $\mathrm{FR}_{2}$ and frontal suture) and two pores $\left(\mathrm{FR}_{\mathrm{b}},{ }^{*} \mathrm{FR}_{\mathrm{cj}}\right)$ on each side. Parietal sclerites smooth with barely visible toothed microsculpture (Figs 5, 8, 57); with 18 setae $\left(\mathrm{PA}_{1-7}, \mathrm{PA}_{9-10}\right.$, $\mathrm{PA}_{12}, \mathrm{PA}_{17}$, two dorsal setae located near $\mathrm{PA}_{3}$ and $\mathrm{PA}_{10}$, four lateral setae and one ventral), eight pores ( $\mathrm{PA}_{\mathrm{a}-\mathrm{b}}, \mathrm{PA}_{\mathrm{d}}, * \mathrm{PA}_{\mathrm{f}}$, $* \mathrm{PA}_{i},{ }^{\mathrm{PA}}$ and lateral pore located near the base of antenna) and single epicranial gland $(\mathrm{Eg})$ on each side.

Antenna (Figs 9-10) with three antennomeres, 0.6 as long as head length. Antennomere I 1.8 as long as wide, dorsally with three pores $\left(\mathrm{AN}_{\mathrm{abb}},{ }^{*} \mathrm{AN}_{\mathrm{c} / \mathrm{d}}\right)$, ventrally with apical pore $* \mathrm{AN}_{\mathrm{d} / \mathrm{e}}$. Antennomere II 1.9 as long as antennomere I and 2.9 as long as wide, with two dorsal $\left(\mathrm{AN}_{1-2}\right)$ and one ventral $\left(\mathrm{AN}_{3}\right)$ setae; also single ventral pore $\left(\mathrm{FR}_{\mathrm{f}}\right)$ present. Its apical part with conical Sa which is 0.4 as long as antennomere III. Also, two smaller sensillae are present ventrally near the base of Sa. Antennomere III 0.35 as long as antennomere II and three as long as wide, with two dorsal $\left(\mathrm{AN}_{4-5}\right)$ and one ventral $\left(\mathrm{AN}_{7}\right)$ setae; its apical part with three elongated sensilla surrounding seta $\mathrm{AN}_{6}$.

Epipharynx (Fig.7) with numerous microtrichia of various length, each side with group of five apical sensillae, two sensillae located posterior, and a group of eight sensillae arranged in a arcuate row with adjacent multiporose structure (Figs 15-16). Posterior part of epipharynx with two sensillae on each side.

Mandibles (Fig. 11) almost symmetrical, slightly curved; each 2.1 as long as basal width, unidentate; incisor edge with serrate margin and single large subapical tooth. Prostheca and mola absent. Basal part with dorsal surface smooth, bearing two pores ( $\left.\mathrm{MN}-\mathrm{MN}_{\mathrm{b}}\right)$; outer edge with two lateral setae ( $\mathrm{MN}$ and seta near the base).

Maxilla (Figs 12-13, see also Fig. 46 of instar III) with somewhat trapezoidal cardo, which is "divided" by the internal sclerotization into two unequal parts - larger proxicardo with smooth surface, and smaller disticardo bearing seta $\mathrm{MX}_{1}$; maxillary articulating area membranous. Ventrally stipes partially divided by less sclerotized area; with two setae ( $\mathrm{MX}_{2-}$ 3). Dorsal side of stipes mostly membranous, except triangular sclerite near the outer margin.

Mala oblique truncate, its proximal part uniformly widened, with a group of microtrichia on inner margin (gMX) and seta located near it; outer margin with two setae and pores; also single pore located near the border of stipes and mala. Distal part gradually narrowed apically, with well developed conical tooth and about 20 lesser projections as well as group of about 25 lateroventral macrosetae (gMX) all along its inner margin (Fig. 13). Apex of mala narrowly longitudinally divided; inner ("lacinial") lobe ventrally bears two mesal slightly curved unci; well developed brush of microtrichia present on its apex; outer ("galeal") lobe with curved conical uncus and ventralseta $* \mathrm{MX}_{0}$. Maxillary palps 3-jointed, palpifer with ventral seta $\mathrm{MX}_{10}$ on its sclerotized part. Palpomere I 1.8 as long as wide, ventrally with two 

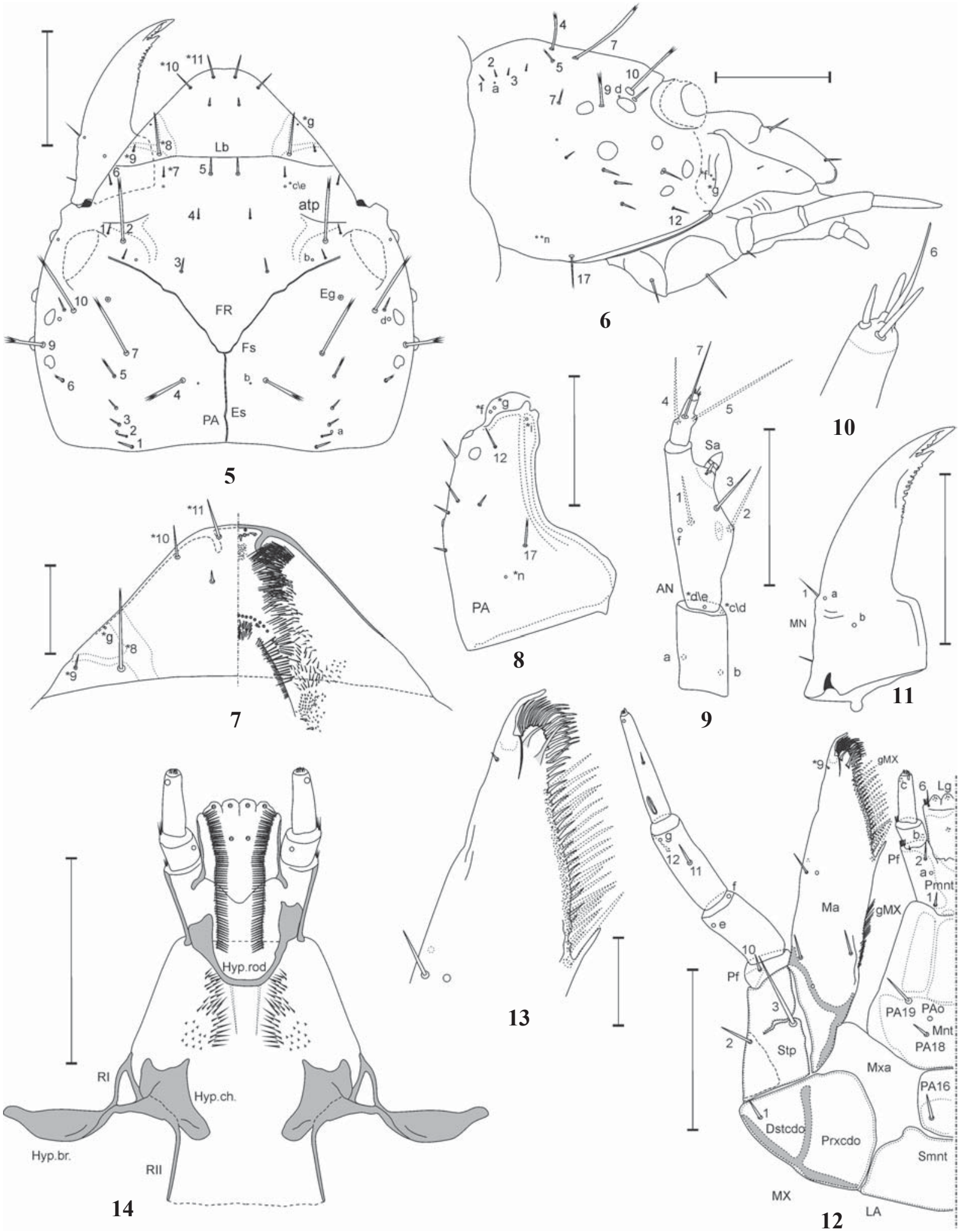

Figs 5-14. Nodynus leucofasciatus, first-instar larva: 5-6 - head; 7 - parietale; 8 - antenna; 9 - apical joint of antenna; 10 - right mandible; 11 - labrum (left - dorsal view, right — ventral view); 12 - labio-maxillar complex; 13 - mala, apical part; 14 - labium; 5, 10, 14 - dorsal view; 6 - lateral view; 7-8, 12-13 - ventral view. Scale bars: $5-10,12,14-0.3 \mathrm{~mm} ; 11,13-0.1 \mathrm{~mm}$.

Рис. 5-14. Nodynus leucofasciatus, личинка первого возраста: 5-6 - голова; 7 - париетальный склерит; 8 - антенна; 9 апикальный членик антенны; 10 - правая мандибула; 11 - верхняя губа (слева - сверху, справа - снизу); 12 - лабиомаксиллярный комплекс; 13 - вершинная часть малы; 14 - нижняя губа; 5, 10, 14 - сверху; 6 - сбоку; 7-8, 12-13 - снизу. Масштаб: 5-10, 12, $14-0,3$ мм, 11, $13-0,1$ мм. 
apical pores (MX ). Palpomere II 1.25 as long as palpomere I and 3.0 as long as wide, its ventral and dorsal side each with single seta $\left(\mathrm{MX}_{11-12}\right)$ and apical pore ( $\mathrm{MX}_{\mathrm{g}}$ and one with uncertain homology). Palpomere III 1.1 as long as palpomere II and 5.5 as long as wide, ventrally with digitiform sensillum near base, one mesal seta and apical pore. Apex of palpomere III with a group of three short conical sensillae.

Labium (Figs 12, 14, 17, 60). Ligula transverse, almost as long as wide, "tetra-lobed" [after Grebennikov, Newton, 2012], dorsally each apical lobe with single sensilla; ventrally with apical seta LA located close to outer margin (Fig. 17). Each side of prementum ventrally with single seta $\mathrm{LA}_{1}$ and pore LA; palpifer with seta $\mathrm{LA}_{2}$, one apical seta and a group of microtrichia on outer apical edge. Labial palps 2-jointed. Palpomere I about as long as wide, dorsally with basal pore $\mathrm{LA}_{\mathrm{b}}$. Palpomere II 1.9 as long as palpomere I and 3.0 as long as wide, dorsally with subapical pore $\mathrm{LA}_{\mathrm{c}}$; apex with a group of four short conical sensilla. Hypopharynx (Fig. 14) with two parallel rows of microtrichia originated from antero-lateral edges of ligula, numerous asperities of various length and single sensilla on each side. Hypopharyngeal sclerotisation well-defined and consists of several structures: 1) hypopharyngeal rod [after Dorsey,1940], originated as paired structure near the base on both sides of prementum which are fusing forming arcuated structure; 2) hypopharyngeal chitinization - paired large sclerotized areas located at the level of latero-basal edges of mentum area; 3 ) hypopharyngeal bracon, which extends from hypopharyngeal chitinization reaching the point of ventral mandibular articulation on anterior part of the hypostomal ridge; 4) a pair of rods, both extending from sclerotized area, one supporting the outer margin of hypopharyngeal region, and other longitudinal, parallel and connected with oesophagus [after Böving, 1921]. Mentum (Figs 12, 60) distinct, trapezoidal, consists of four sclerites: single large posterior, lacking asperities and bearing two setae $\left(\mathrm{PA}_{18-19}\right)$ and pore $\mathrm{PA}$ on each side; three anterior sclerites without sensilla. Submentum divided into two parts, posterior entirely sclerotized, smooth and lacks setae; anterior partly membranous, its sclerotized part also smooth and bears seta $\mathrm{PA}_{16}$ on each side.

Thorax (Figs 21-23, 63, 66). Cervicosternum consists of paired presternum with two setae each and single eusternum with two setae on each side (all composing gPS).

Thorax about 0.3 as long as total body length, widest across prothorax. Prothorax is 0.6 as long as wide, 1.3 as long as mesothorax and 1.5 as long as metathorax.

Thoracic tergites with smooth surface (Figs 63, 66), meso- and metanotum differ in presence of anterior carina with group of medial asperities, possibly egg-bursters (Fig. 21). Ecdysial line well defined on all thoracic segments. Thoracic pleurites and sternites smooth, membranous areas covered in microtrichia. Mesothoracic spiracle annular (Figs 18, 24), metathoracic spiracle rudimentary (Figs 22-23).

Chaetotaxy (Figs 21-23). Prothorax: each side of pronotum with 16 setae $\left(\mathrm{PR}_{1-14}\right.$, one seta on anterior margin, other one located between $\mathrm{PA}_{8}$ and $\left.\mathrm{PA}_{14}\right)$ and eight pores $\left(\mathrm{PR}_{\mathrm{b}-\mathrm{e}}\right.$, $\mathrm{PR}_{\mathrm{b}}, \mathrm{PR}_{\mathrm{t}}$ ), with well developed pretergal gland located near pore $\mathrm{PR}_{\mathrm{d}}$. Episternum with four setae $\left(\mathrm{ES}_{1-4}\right)$; epimeron with single seta $\mathrm{EM}_{1}$; prosternite with two setae $\left(\mathrm{PS}_{1-2}\right)$.

Mesothorax: mesonotum with 15 setae $\left(\mathrm{ME}_{1-14}\right.$; seta located between $\mathrm{ME}_{11}$ and $\left.\mathrm{ME}_{12}\right)$ and five pores $\left(\mathrm{ME}_{\mathrm{a}-\mathrm{b}}, \mathrm{ME}_{\mathrm{d}-\mathrm{e}}\right.$, $\mathrm{ME}_{\mathrm{g}}$ ) on each side; pretergal gland located near seta $\mathrm{ME}_{6}$, also another glandular structure (Tg) present in the medial part of sclerite. Episternum divided into two sclerites: smaller anterior on which spiracle is located, with single seta ES, and larger posterior one with two setae $\left(\mathrm{ES}_{5-6}\right)$. Epimeron with single seta $\mathrm{EM}_{1}$; pleurite also with single seta $\mathrm{PL}_{1}$. Mesosternite with four setae on each side (MS ${ }_{14}$ ). Chaetotaxy of metathorax is almost identical except the reduction of seta $\mathrm{ME}_{5}$.
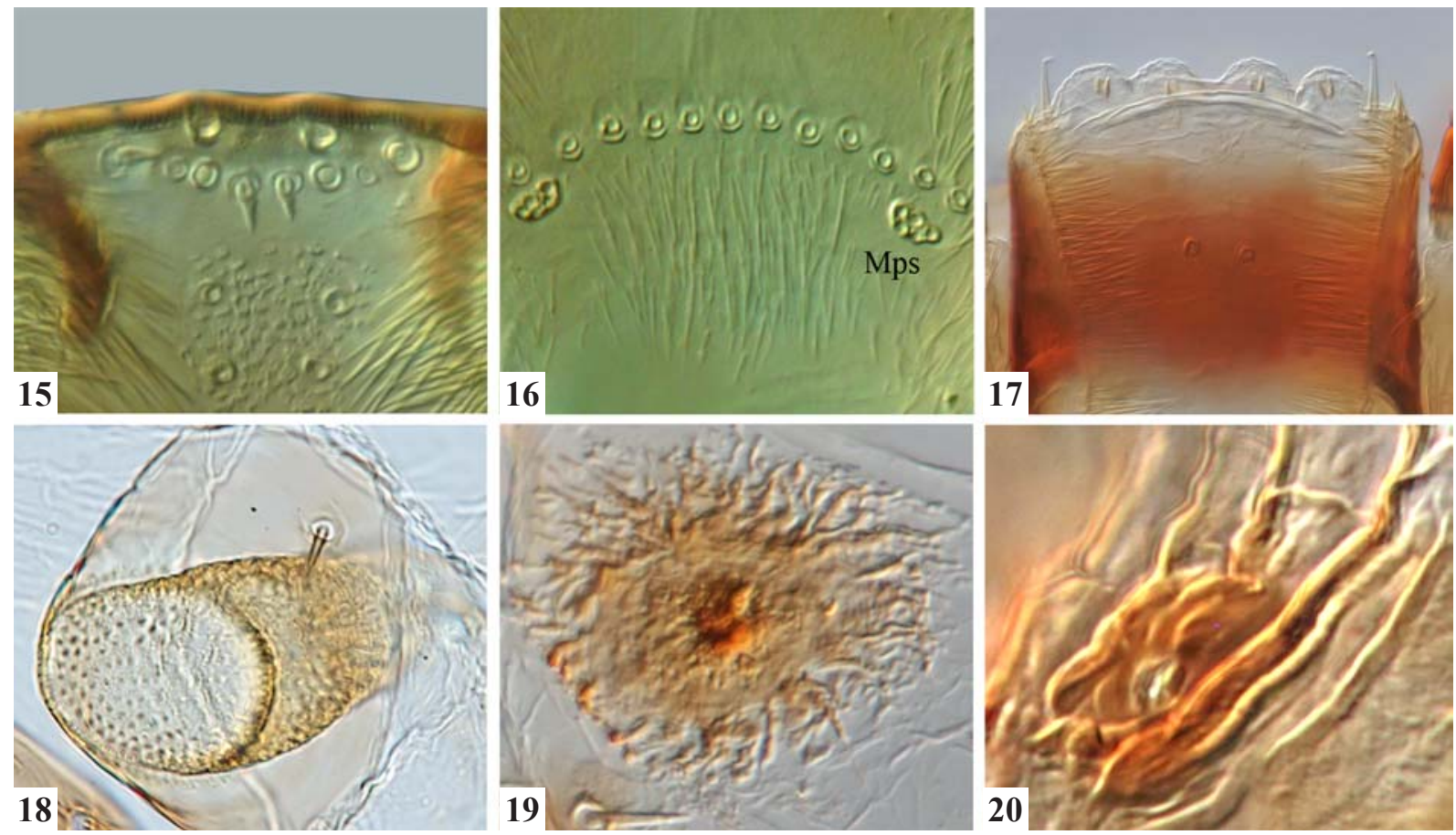

Figs 15-20. Nodynus leucofasciatus, first-instar larva: 15-16 - epipharyngeal sensillae; 17 — ligula; 18 - mesothoracic spiracle; 19 abdominal segment I, “pleuropodium”; 20 - abdominal segment IX, pretergal gland. Not to scale.

Рис. 15-20. Nodynus leucofasciatus, личинка первого возраста: 15-16 - сенсиллы эпифаринкса; 17 - лигула; 18 - среднегрудное дыхальце; 19 - I брюшной сегмент, “pleuropodium”; 20 - IX брюшной сегмент, железа на передней части тергита. Не в масштабе. 

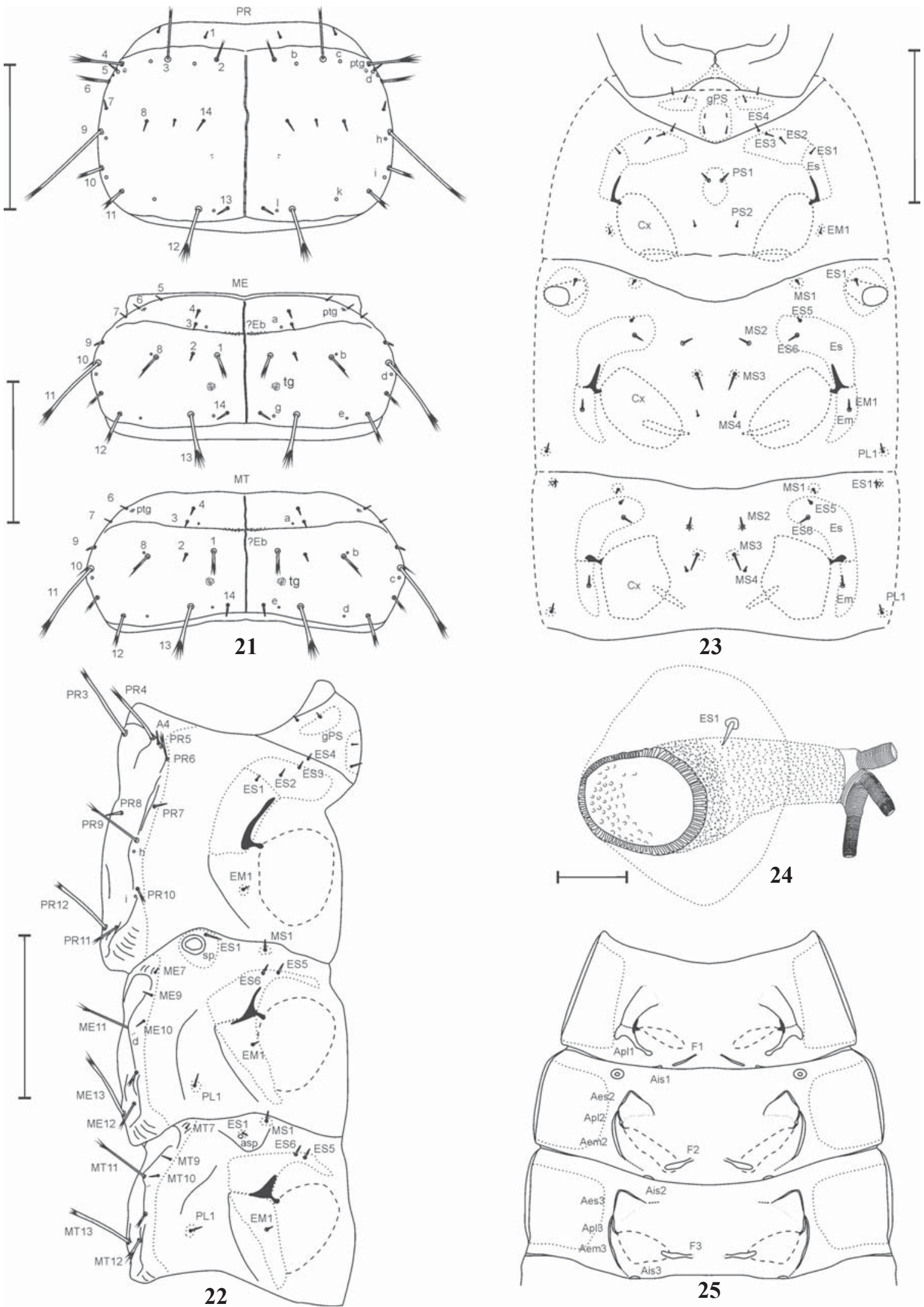

Figs 21-25. Nodynus leucofasciatus, first-instar larva, thorax: 21 - dorsal view, 22 - lateral view, 23 - ventral view; 24 - mesothoracic spiracle; $25-$ thoracic endoskeleton. Scale bars: $21-23-0.5 \mathrm{~mm} ; 24-0.05 \mathrm{~mm}$.

Pис. 21-25. Nodynus leucofasciatus, личинка первого возраста, грудной отдел: 21 - сверху, 22 - сбоку, 23 - снизу; $24-$ среднегрудное дыхальце; 25 - эндоскелет груди. Масштаб: $21-23-0,5$ мм; $24-0,05$ мм. 
Thoracic endoskeleton (Fig. 25). Prothorax: pleural apodemes rectangular, bifurcated, with long apical process; profurcae elongated, narrowed; intersegmental apodemes small, with broad base. Meso- and metathorax with well developed episternal and epimeral apodemes; pleural apodemes reduced; meso- and metafurcae distinctly wider than profurcae; intersegmental apodemes similar to those on prothorax.

Legs (Figs 26-27, 75) 5-jointed, its surface smooth, all three pairs similar in structure and chaetotaxy; length ratio of its joints to coxa is $0.5: 1.25: 1.25: 0.8$. Coxa with 18 setae (basal $\mathrm{CO}_{1-3}$; anterior $\mathrm{CO}_{9-10}$; posterior $\mathrm{CO}_{11}$; eight anterior and four posterior setae of uncertain homology) and two pores $\left(\mathrm{CO}_{\mathrm{a}-\mathrm{b}}\right)$. Trochanter with eight setae (anterior $\mathrm{TR}_{1-3}$; posterior $\mathrm{TR}_{5-7}$; ventral $\mathrm{TR}_{4}$; one anterior apical seta of uncertain homology) and seven pores (anterior $\mathrm{TR}_{\mathrm{a}-\mathrm{e}} ;$ posterior $\mathrm{TR}_{\mathrm{f}-\mathrm{g}}$ ). Femur with a group of anterior asperities near apex; with eight setae (anterior $\mathrm{FE}_{2}, \mathrm{FE}_{3}, \mathrm{FE}_{6}$; posterior $\mathrm{FE}_{4-5}$; dorsal $\mathrm{FE}_{1}$; one anteri- or and posterior setae of uncertain homology) and two pores $\left(\mathrm{FE}_{\mathrm{a}-\mathrm{b}}\right)$. Tibiotarsus with nine setae (anterior $\mathrm{TI}_{2-4}, \mathrm{TA}_{1-2} ;$ posterior $\mathrm{TI}_{5-7}, \mathrm{TA}_{7}$ ) and two anterior pores $\left(\mathrm{TA}_{\mathrm{ab}}\right)$. Pretarsus with single long and sharp claw bearing two setae $\left(\mathrm{UN}_{1-2}\right)$.

Abdomen (Figs 28-32, 69, 72). About 0.4 as long as total body length, widest across abdominal segment V. Abdominal tergites (AT) I-IX with smooth surface, anterior carina present (Fig. 69); AT I-VIII with medial group of asperities located posterior from carina. Abdominal pleurites, sternites and membranous areas smooth (Fig. 72). Position and structure of pleural sclerites varies significantly (Fig. 31): abdominal segment I with epipleurite consisting of two small sclerites, and single small hypopleurite; abdominal segments II-III each with single fused epipleurite and much larger hypopleurite; abdominal segment IV with epipleurite fused with tergite and hypopleurite get closer to sternite; abdominal segments V-IX with both epipleurite and hypopleurite fused with

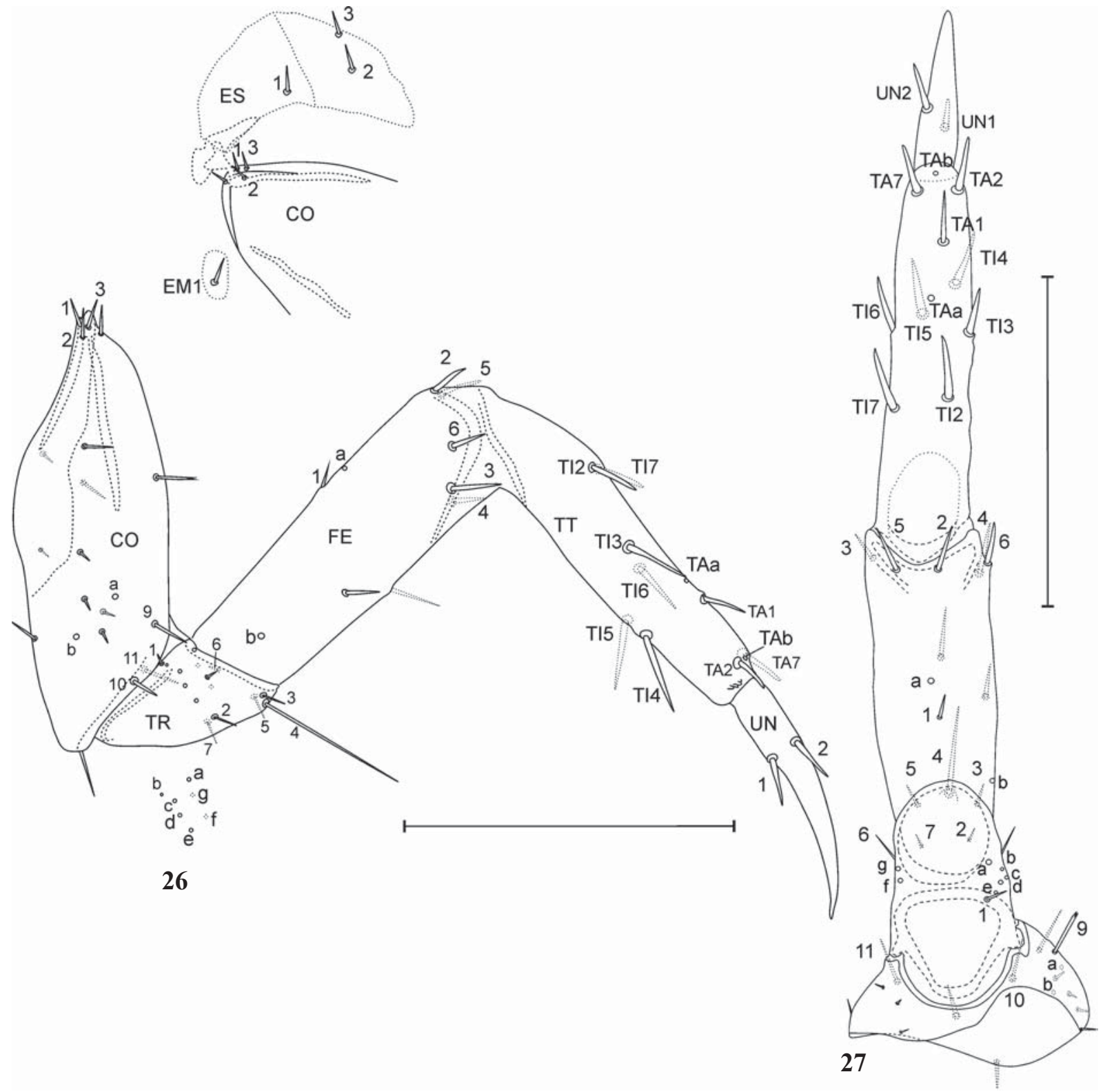

Figs 26-27. Nodynus leucofasciatus, first-instar larva, fore leg: 26 - anterior view; 27 - dorsal view. Scale bars: $0.5 \mathrm{~mm}$.

Рис. 26-27. Nodynus leucofasciatus, личинка первого возраста, нога первой пары: 26 - спереди; 27 - сверху. Масштаб: 0,5 мм. 
tergite and sternite respectively. Moreover, on each side of abdominal segment I, close to anterior epipleural sclerite, heavy sclerotized area with small medial projection located (Figs 18, 29). Most likely it appears to be the remains of socalled «pleuropodium» - the structure which is thought to facilitate the process of hatching [Kobayashi et al, 2003] and was observed earlier in larvae of various families of Coleoptera, but as far as we know never for Staphylinidae.

Abdominal spiracles annular (Fig. 31). Urogomphi (Figs $32,78)$ 2-jointed, 0.3 as long as total body length; basal joint 2.1 as long and 2.5 as wide as apical one. Surface of urogomphi with rather weak scale-like sculpture. Pygopod (abdominal segment $\mathrm{X}$ ) about 1.7 as long as abdominal segment IX; its apex with five membranous eversible lobes with numerous small hooks (Fig. 32); dorsal surface covered in numerous small asperities, ventral smooth.

Chaetotaxy (Figs 28-32). Each side of AT I-III with 10 setae $\left(\mathrm{TE}_{1-4}, \mathrm{TE}_{6-11}\right)$, three pores $\left(\mathrm{TE}_{2}, \mathrm{TE}_{c-\mathrm{d}}\right)$ and pretergal gland located close to $\mathrm{TE}_{3}$. AT IV-VIII have similar chaetotaxy but differ by presence of two setae $\left(\mathrm{EP}_{1-2}\right)$, as a result of fusion with epipleurite. AT IX with three setae $\left(\mathrm{UR}_{1-3}\right)$, one pore located near UR and pretergal gland (Fig. 20). Basal joint of each urogomphi with six setae $\left(\mathrm{UR}_{4-5}\right.$; one dorsal, two lateral and one ventral setae) and two pores (UR, UR ); apical joint with three setae $\left(\mathrm{UR}_{8-9}\right.$ and one ventral seta) and a single pore. Epipleurite of abdominal segments I-III with two setae $\left(\mathrm{EP}_{1-2}\right)$; hypopleurite of abdominal segment I with single seta ${ }^{*} \mathrm{HY}_{1}$, on abdominal segments II-IV with two setae ( $\left.\mathrm{HY}_{1-2}\right)$. Abdominal sternite (AS) I consists of two pairs of small sclerites, each with single seta $\left(\mathrm{ST}_{1}, \mathrm{ST}_{4}\right)$, and single large sclerite with two setae ( $\mathrm{ST}_{2-3}$ ) on each side. AS II-IV consists of single large sclerite with 5 setae $\left(\mathrm{ST}_{1-5}\right)$ on each side; AS VVIII with two extra setae $\left(\mathrm{HY}_{1-2}\right)$ as a result of fusion with hypopleurite. AS IX with 6 setae $\left(\mathrm{ST}_{1}, \mathrm{ST}_{3-5}, \mathrm{ST}_{2}, * \mathrm{ST}_{6}\right)$. Pygopod dorsally with 3 setae (PY ${ }$ ) and single pore PYa, ventrally with three setae (PY ${ }_{6-7}$ and one apical seta) and two pores $\left(\mathrm{PY}_{\mathrm{f}}\right.$ and one lateral pore).

\section{Second-instar larva}

Figs 33-42.

Differences from the first instar are the following. Body length $8.2 \mathrm{~mm}$; head length $1.3 \mathrm{~mm}$; head width $1.5 \mathrm{~mm}$, urogomphi length $2.2 \mathrm{~mm}$; maximum width of thorax 1.8 $\mathrm{mm}$; maximum width of abdomen $1.6 \mathrm{~mm}$. Body widest across mesothorax (Fig. 2). Most setae increase in size in comparison with first instar.

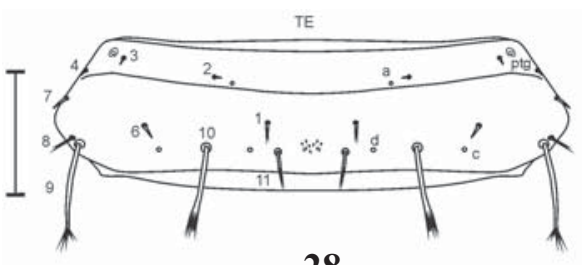

28
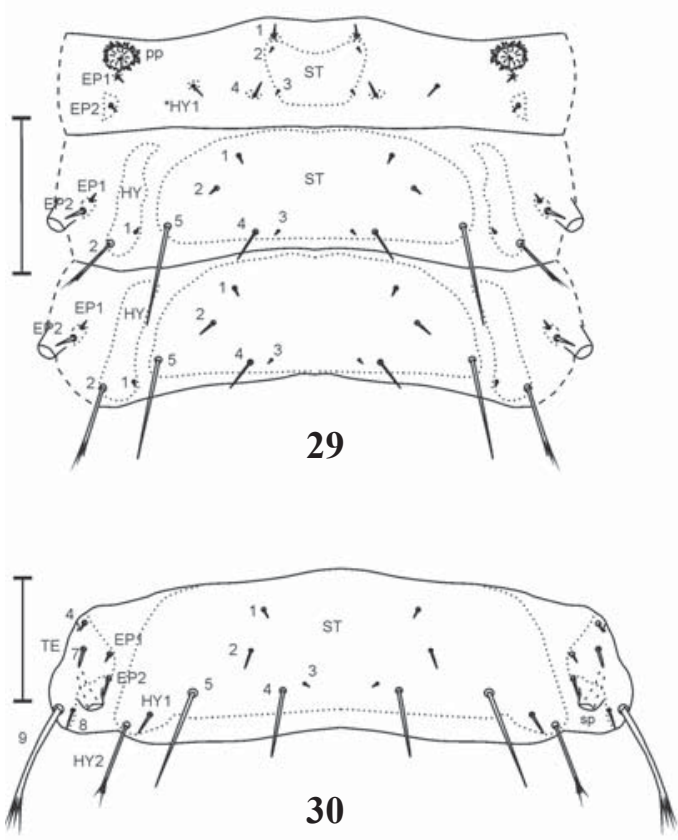
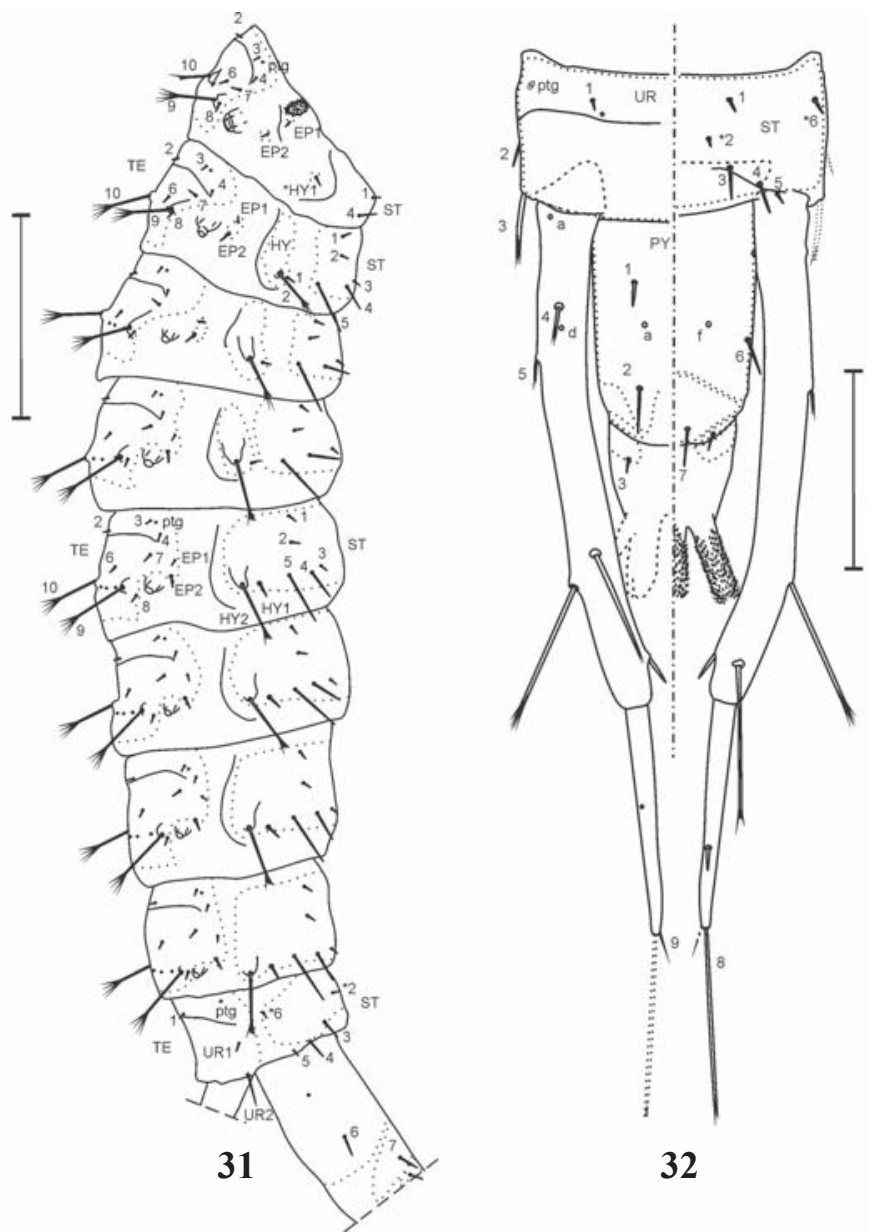

32

Figs 28-32. Nodynus leucofasciatus, first-instar larva. 28 - abdominal segment V; 29 — abdominal segments I-III; 30 - abdominal segment VI; 31 - abdominal segments I-X; 32 - abdominal segments IX-X (left — dorsal view, right — ventral view); 28 - dorsal; 29 30 - ventral; 31 - lateral. Scale bars: $28-30-0.3 \mathrm{~mm} ; 31-32-0.5 \mathrm{~mm}$.

Рис. 28-32. Nodynus leucofasciatus, личинка первого возраста. 28 - V брюшной сегмент; 29 - I-III брюшные сегменты; 30 VI брюшной сегмент; 31 - I-X брюшные сегменты; 32 - IX-X брюшные сегменты (слева — сверху, справа - снизу); 28 - сверху; 29-30 - снизу; 31 - сбоку. Масштабные линейки: 28-30-0.3 мм; 31-32-0.5 мм. 


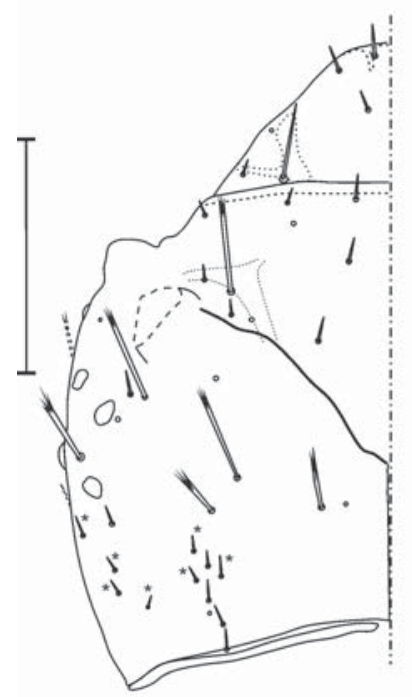

33
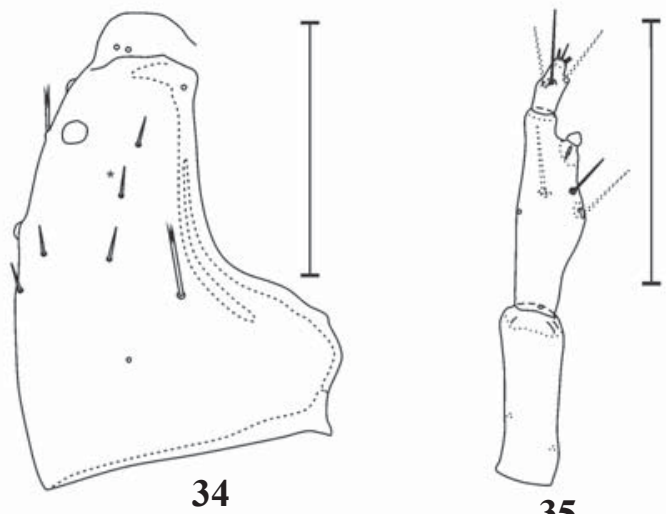

35

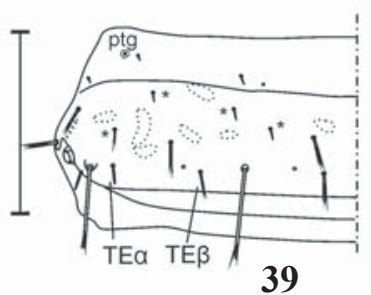

39

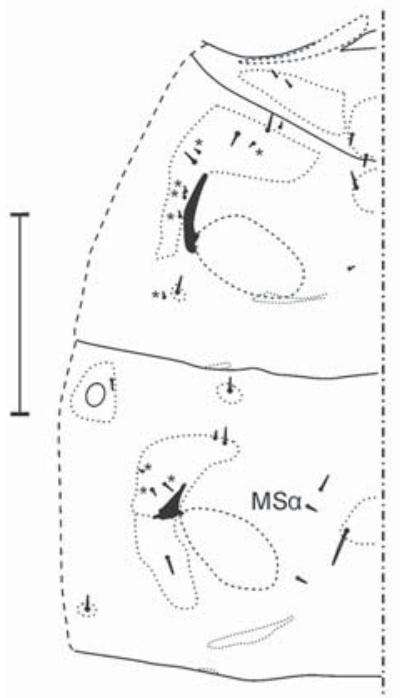

37

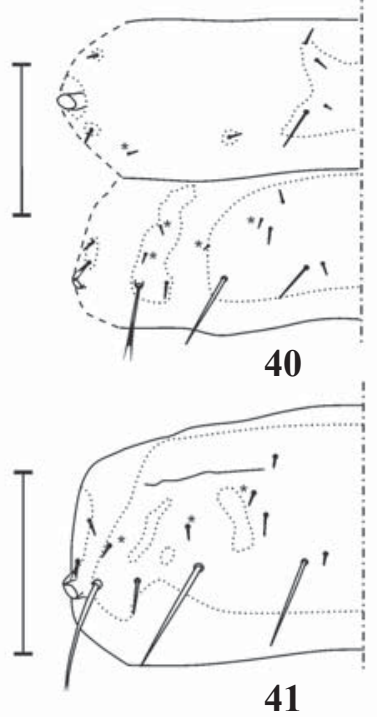

41
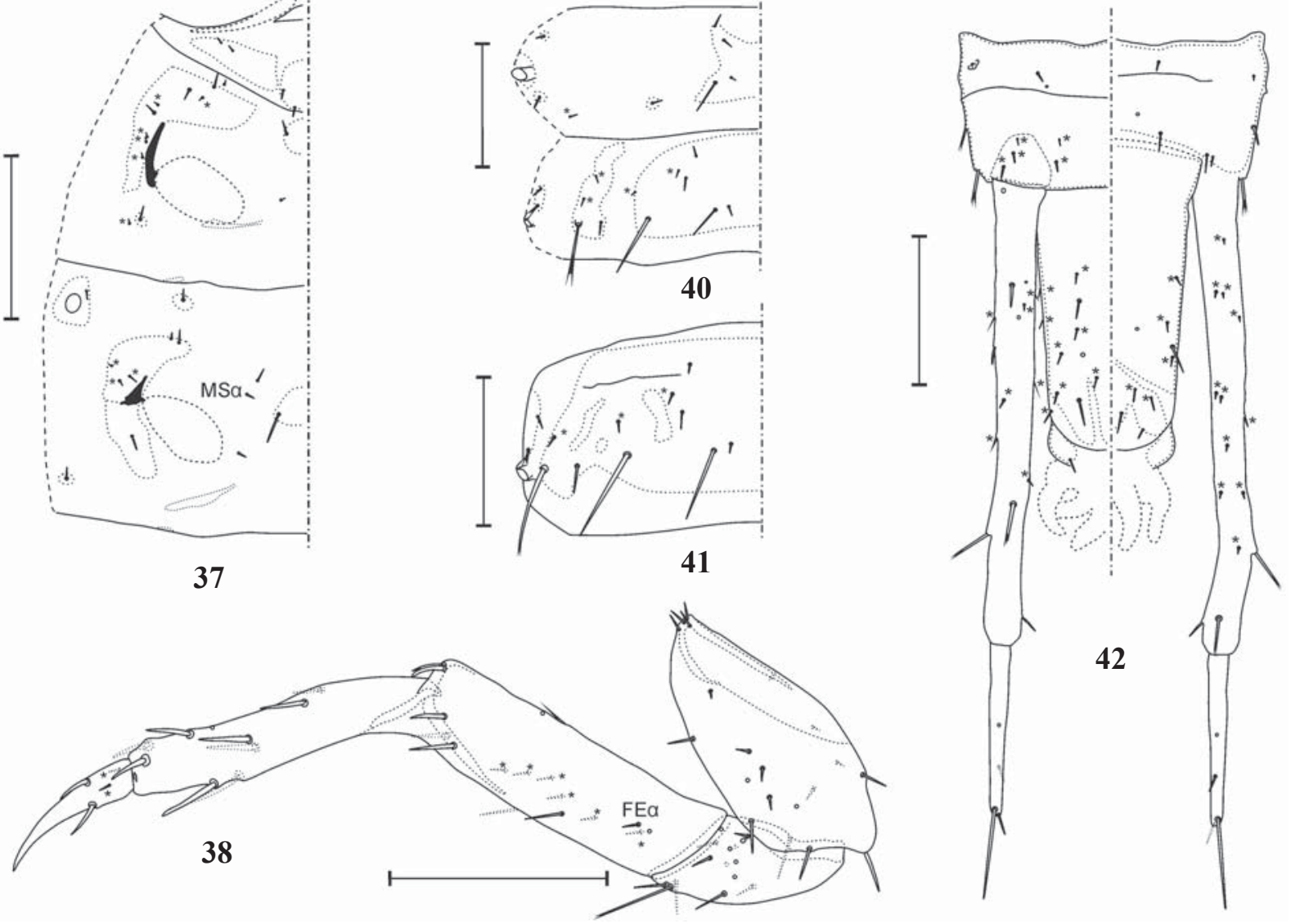

Figs 33-42. Nodynus leucofasciatus, second-instar larva: 33 - head; 34 - parietale; 35 — antenna; 36 - pro- and mesothorax; 37 pro- and mesothorax; 38 - fore leg; 39 - abdominal segment V; 40 - abdominal segments I-II; 41 - abdominal segment VI; 42 - abdominal segments IX-X (left — dorsal view, right - ventral view); 33, 36-37, 39 — dorsal view; 34-35, 40-41 - ventral view; 38 - anterior view. Scale bars: $0.5 \mathrm{~mm}$. Secondary setae marked with *.

Рис. 33-42. Nodynus leucofasciatus, личинка второго возраста: 33 - голова; 34 - париетальный склерит; 35 - антенна; 36 передне- и среднегрудь; 37 - передне- и среднегрудь; 38 - нога первой пары; 39 - V брюшной сегмент; 40 - I-II брюшные сегменты; 41 - VI брюшной сегмент; 42 - IX-X брюшные сегменты (слева — сверху, справа — снизу); 33, 36-37, 39 — сверху; 34-35, 40-41 - снизу; 38 - спереди. Масштаб: 0,5 мм. Вторичные хеты обозначены *. 


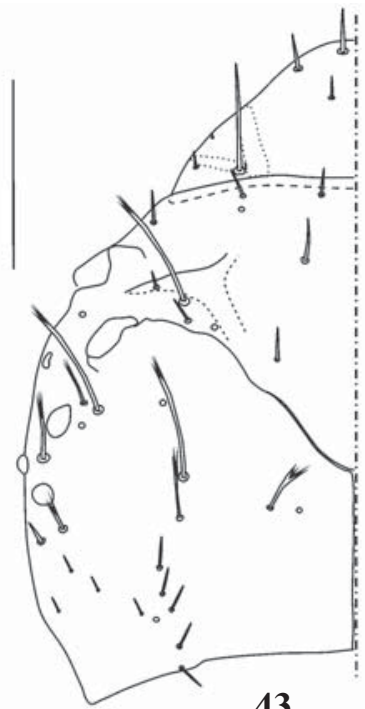

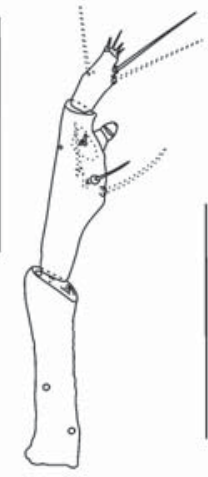

44

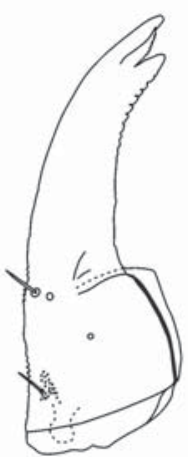

45

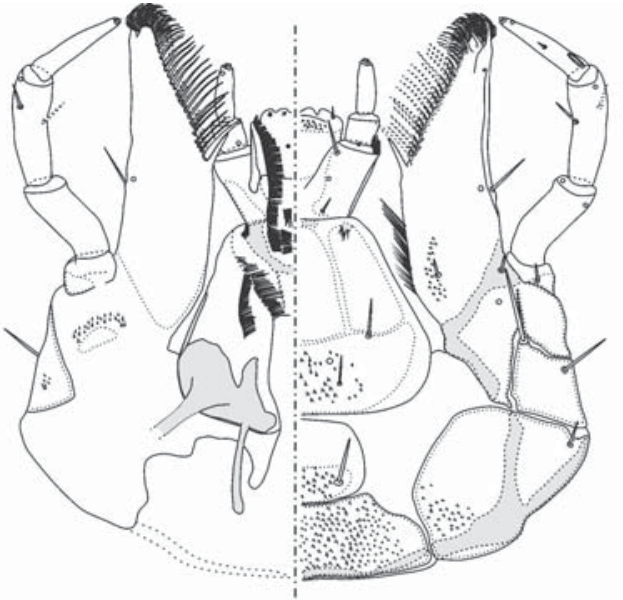

46
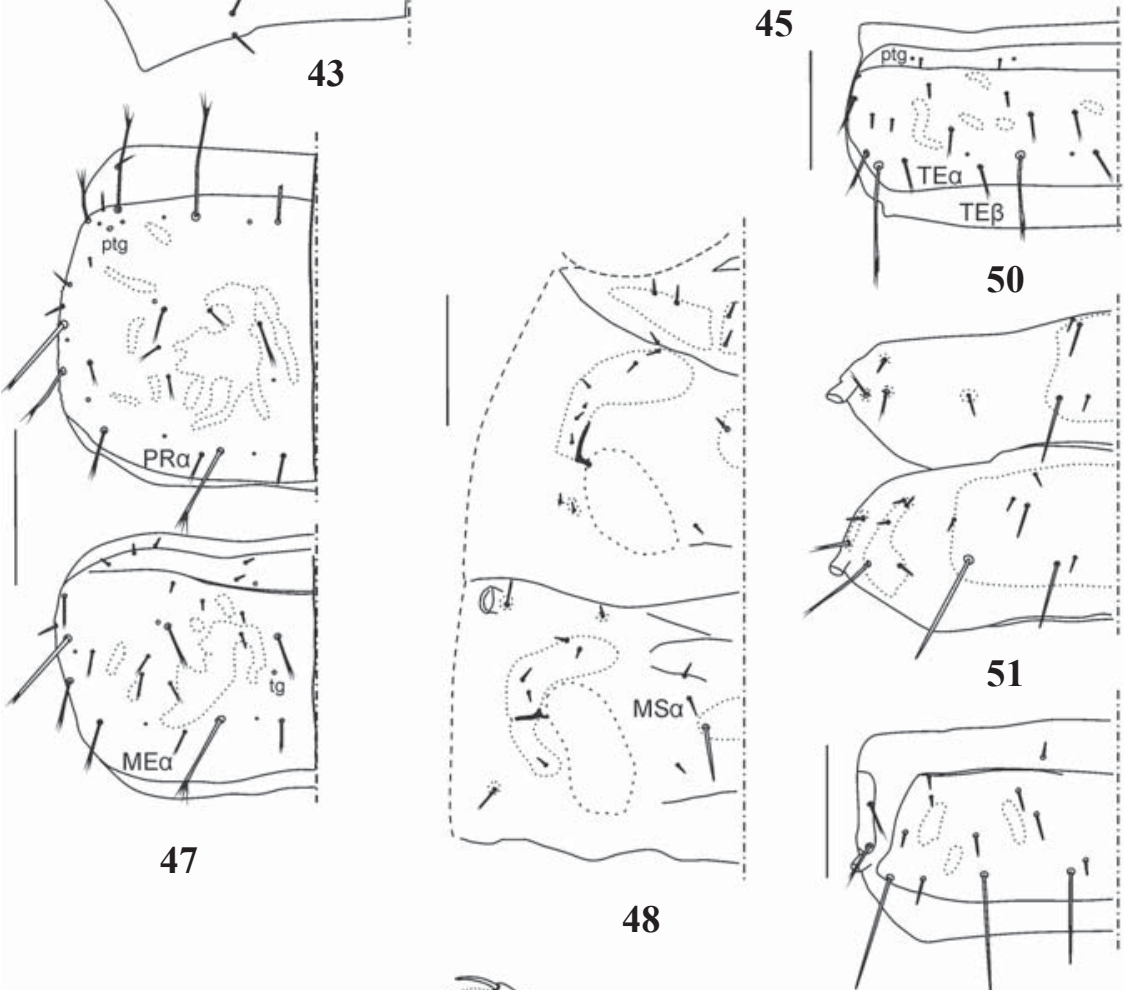

48
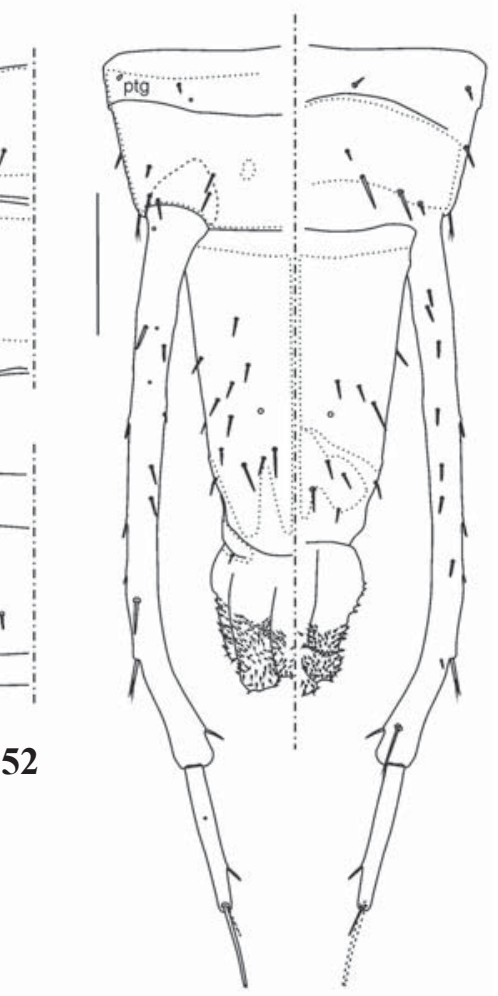

53

Figs 43-53. Nodynus leucofasciatus, third-instar larva: 43 - head; 44 — antenna; 45 — right mandible; 46 - labio-maxillar complex (left - ventral view, right — dorsal view); 47 — pro- and mesothorax; 48 - pro- and mesothorax; 49 - fore leg; 50 - abdominal segment V; 51 - abdominal segments I-II; 52 — abdominal segment VI; 53 - abdominal segments IX-X (left — dorsal view, right — ventral view); 43, 45, 47, 50 - dorsal view; 44, 48, 51-52 — ventral view; 49 - anterior view. Scale bars: $0.5 \mathrm{~mm}$.

Рис. 43-53. Nodynus leucofasciatus, личинка третьего возраста: 43 — голова; 44 - антенна; 45 - правая мандибула; 46 - лабиомаксиллярный комплекс (слева — снизу, справа — сверху); 47 - передне- и среднегрудь; 48 - передне- и среднегрудь; 49 - нога первой пары; 50 - V брюшной сегмент; 51 - I-II, брюшные сегменты; 52 - VI брюшной сегмент; 53 - IX-X брюшные сегменты (слева - сверху, справа - снизу); 43, 45, 47, 50 - сверху; 44, 48, 51-52 - снизу; 49 - спереди. Масштаб: 0,5 мм. 
Head (Figs 33-34). Frontal sclerites with more developed honeycomb pattern (Fig. 55); parietal sclerites with distinct honeycomb pattern and more developed toothed microsculpture (Fig. 58); with five-six secondary setae dorsally and one-two secondary setae ventrally (Figs 33-34).

Antenna (Fig. 35) 0.8 as long as head length. Antennomere I 4.8 as long as wide. Antennomere II 1.1 as long as antennomere I and 3.0 as long as wide; conical sensorial appendage (Sa) 0.3 as long as antennomere III; additional sensilla located near $\mathrm{AN}_{1}$. Antennomere III 0.3 as long as antennomere II and 2.0 as long as wide.

Proxicardo and sclerotised areas of submentum partly covered in short asperities (Fig. 61).

Thorax (Figs 36-37). Pronotum partly with microgranulated sculpture, except distinct smooth strongly sclerotised areas (Fig. 64); meso- and metanotum partly covered in asperities, without group of medial asperities associated with anterior carina (Fig. 67). Prothoracic episternum, meso- and metathoracic epimeron and sternal sclerites covered with small asperities.

Chaetotaxy (Figs 36-37). Prothorax: pronotum with threefour secondary setae and additional seta $\mathrm{PR}_{\alpha}$; episternum with four-five secondary setae; epimeron with single additional seta $\mathrm{EM}_{\alpha}$. Meso- and metathorax: meso- and metanotum with fiveseven secondary setae and additional seta $\mathrm{ME}_{\alpha}$; episternum with two-three secondary setae; meso- and metasternite with additional seta $\mathrm{MS}$.

Legs (Figs 38, 76). Surface of coxa and femur partly with honeycomb pattern (Fig. 76). Femur with four-six posterior secondary setae and one additional anterior seta $\mathrm{FE}_{\alpha}$ close to $\mathrm{FE}_{\mathrm{b}}$. Claw with two additional setae $\mathrm{UN}_{\alpha-\beta}$ (Fig. 41).

Abdomen (Figs 39-42). AT I-IX covered in more asperities, which absent on strongly sclerotised areas (Fig. 70). Abdominal pleurites mostly smooth, sternites partly covered in asperities (Fig. 73). AS V-VII with incomplete anterior carina, AS VIII-IX with almost complete anterior carina. Remains of pleuropodium on AS I absent.

Urogomphi 0.25 as long as total body length; basal joint 2.7 as long and 2.3 as wide as apical one. Surface of urogomphi with more developed scale-like sculpture (Fig. 79). Dorsal surface of pygopod with larger asperities.

Chaetotaxy (Figs 39-42). AT I-VIII with four-five secondary setae and two additional setae $\left(\mathrm{TE}_{\alpha-\beta}\right)$. AT IX with five secondary setae; basal joint of each urogomphi with fiveseven secondary setae dorsally and eight-ten ventrally (Fig. 42). Hypopleurite of abdominal segments II-IV with twothree secondary setae. Abdominal sternite I consists of single large sclerite with setae $\mathrm{ST}_{1-4}$. Abdominal sternites II-VIII with two-three secondary setae. Pygopod dorsally with seveneight secondary setae, ventrally with five secondary setae.

\section{Third-instar larva \\ Figs 43-53.}

Differences from the instar II are the following. Body length $12.3 \mathrm{~mm}$; head length $1.7 \mathrm{~mm}$; head width $1,8 \mathrm{~mm}$, urogomphi length $2.5 \mathrm{~mm}$; maximum width of thorax 2.4 $\mathrm{mm}$; maximum width of abdomen $2.5 \mathrm{~mm}$ (Fig. 3). Most setae increase in size in comparison with second instar.

Head (Fig. 43). Frontal sclerites more sclerotised with distinct honeycomb pattern (Fig. 56); parietal sclerites with much larger asperities (Fig. 59). Chaetotaxy is the same as in second-instar larva (Fig 43).

Antenna (Fig. 44) 0.7 as long as head length. Antennomere I 5.0 as long as wide. Antennomere II 0.8 as long as antennomere I and 3.1 as long as wide; conical sensorial appendage (Sa) 0.4 as long as antennomere III. Antennomere III 0.5 as long as antennomere II and 3 as long as wide.
Mandible (Fig. 45). Dorsal surface of each mandible in basal part with a group of small cuticular spines.

Dorsal triangular sclerite near the outer margin of stipes with medial asperities, small dorsal medial sclerite partially surrounded with asperities. Mala with asperities near the inner margin (Fig. 46). Sclerotized areas of submentum and mentum entirely covered with stout asperities (Fig. 62).

Thorax (47-48). Pronotum mostly covered in distinctly larger granulae (Fig. 65); meso- and metanotum almost entirely covered in large asperities (Fig.68). Pretergal glands visible only on pronotum, tergal glands distinct on all segments. Thoracic pleurites and sternites with asperities arranged in short rows. Chaetotaxy is the same as in second instar (47-48).

Legs (Fig. 49). Entire surface of all joints except claw with asperities arranged in short rows (Fig. 77). Chaetotaxy is the same as in second instar.

Abdomen (50-53). Almost all surface of AT I-IX covered in stout asperities (Fig. 71). Abdominal pleurites and sternites with asperities arranged in short rows (Fig. 74). AS VIII-IX with complete anterior carina.

Urogomphi 0.2 as long as total body length; basal joint 4.0 as long and 1.6 as wide as apical one. Surface of urogomphi with more developed scale-like sculpture (Fig. 80). Dorsal surface of pygopod with stout asperities, most of them arranged in short rows; most of ventral surface with similar asperities, which are less developed in medial part.

\section{Difference between Apatetica and Nodynus larvae}

Major differences between Apatetica and Nodynus larvae were pointed out before [Grebennikov, Newton, 2012], such as antenna exceeding head capsule length (much shorter in Nodynus) and 1-jointed urogomphi, exceeding abdomen length (much shorter and 2-jointed in Nodynus). However, larvae of Apatetica, studied by Grebennikov and Newton, had both urogomphi broken, so the number of joints should be revised. Additional difference is ligula apically covered in numerous microtrichia in Apatetica (smooth in Nodynus).

\section{Taxonomic position of Apateticinae based on larval characters}

As was mentioned above,there are several principal views on taxonomic position of Apateticinae, which will be briefly discussed here on the basis of larval characters. It should be noted that these results are preliminary and separate study with additional data on larval morphology (including chaetotaxy) of various groups of Staphylinoidea is needed. 1979].

A group within Silphidae, part of Silphinae [Madge,

Apateticinae larvae share some common features with those of Silphinae, such as six pairs of stemmata, similar shape of mandibles and hypopharyngeal sclerotization as well as presence of multiporose structures on epipharynx. But most of these attributes can also be found in other staphylinid subfamilies, so cannot be considered as the proof of close relationship. For instance, similar mandible structure is characteristic for some Aleocharinae, Omaliinae, Trigonurinae, etc [Steel, 1970; Pototskaya, 1976]; six pairs of stemmata are present in some Scaphidiinae, all Trigonurinae, Glypholomatinae and other groups [Thayer, 2005]; multi- 

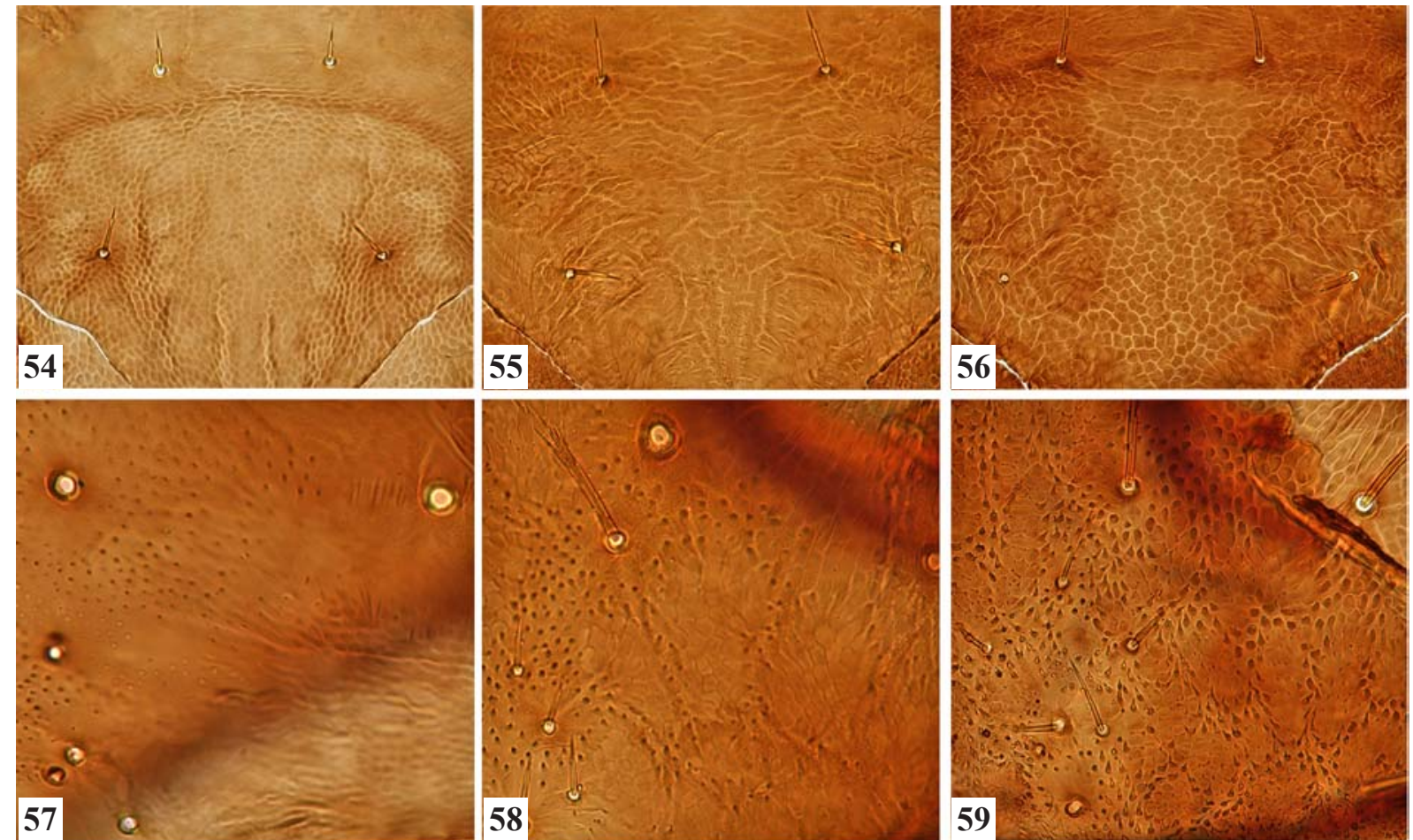

57
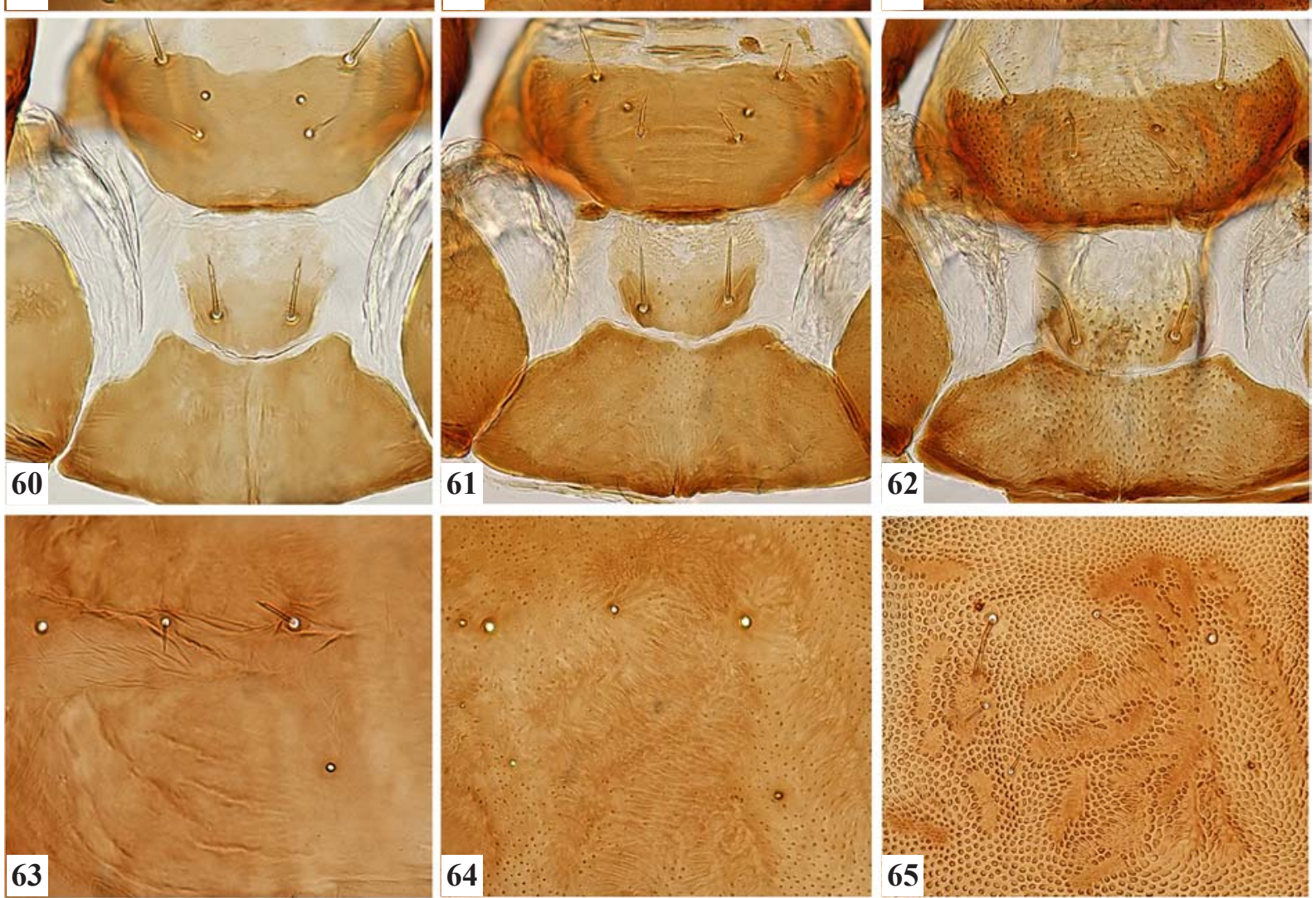

Figs 54-65. Nodynus leucofasciatus, microsculpture: 54, 57, 60, 63 - larva I instar; 55, 58, 61, 64 - II instar, 56, 59, 62, 65 - III instar; 54-56 - frontale; 57-59 - parietale; 60-62 - labium, submentum and mentum; 63-65 - pronotum. Not to scale.

Pис. 54-65. Nodynus leucofasciatus, микроскульптура: 54, 57, 60, 63 - личинка I возраста; 55, 58, 61, 64 — II возраста; 56, 59, 62, 65 - III возраста: 54-56 - фронтальный склерит; 57-59 - париетальный склерит, сверху; 60-62 — нижняя губа, субментум и ментум; 63-65 - пронотум. Не в масштабе. 
porose structures on epipharynx also developed in some Tachyporinae, Aleocharinae and Phloeocharinae [Ashe, Newton, 1993; Ashe, 2005]. Hypopharyngeal sclerotisation is poorly studied in staphylinid larvae and its similar structure can be possibly found in other repre- sentatives of the family. At the same time, Apateticinae larvae differ from those of Silphinae by presence of modified (apically frayed) setae as well as epicranial and tergal glands.

Moreover, typical Silphinae larval features such as

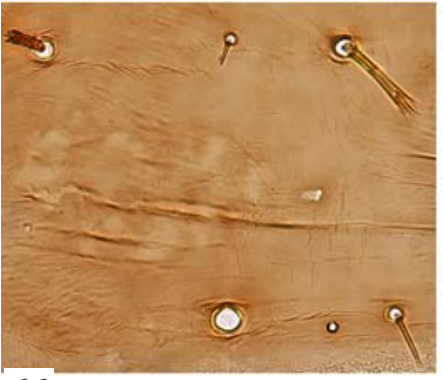

66

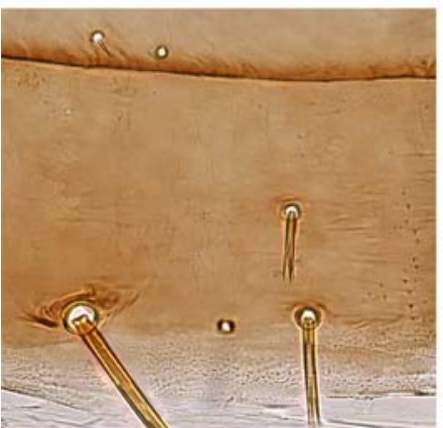

69

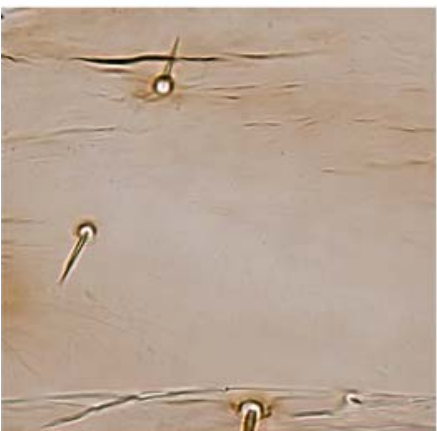

72

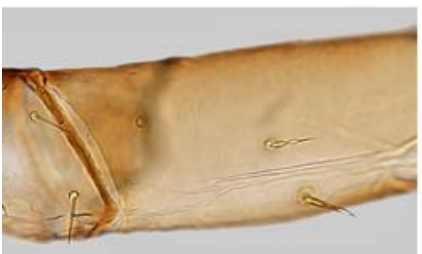

75

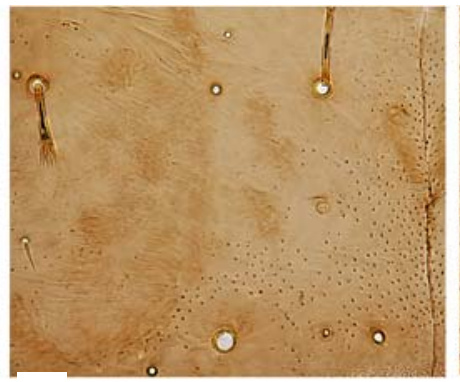

67

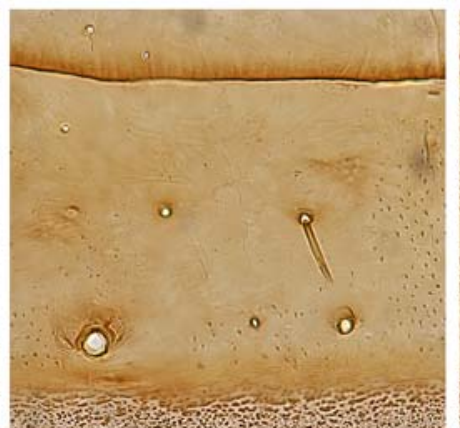

70

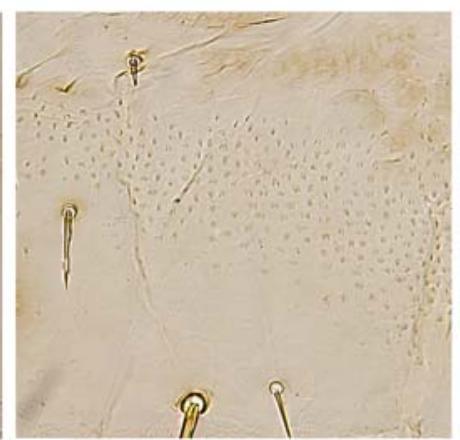

73

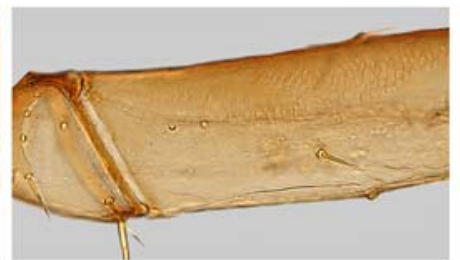

76

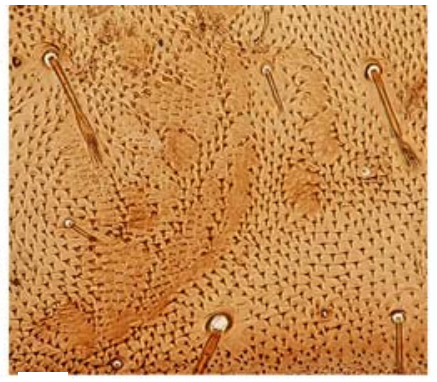

68

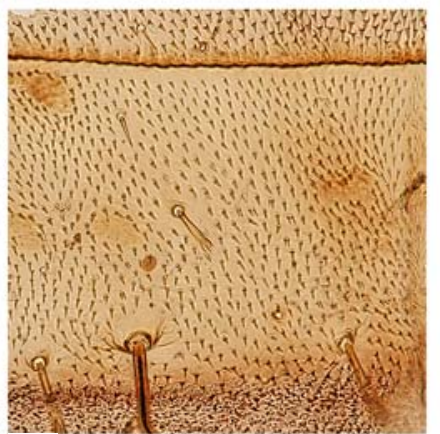

71

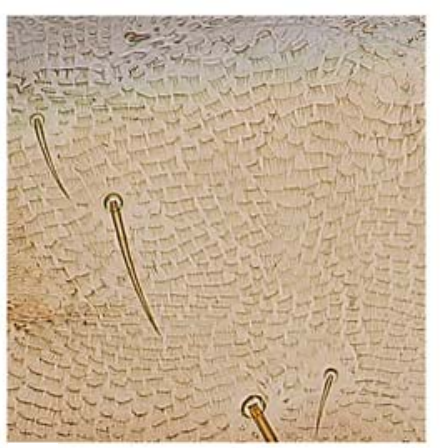

74

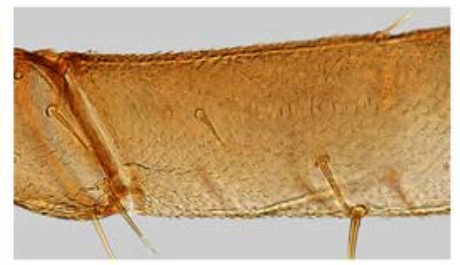

77

Figs 66-80. Nodynus leucofasciatus, microsculpture: 66, 69, 72, 75, 78 - larva I instar; 67, 70, 73, 76, 79 - II instar; 68, 71, 74, 77, 80 - III instar; 66-68 - mesonotum; 69-71 - abdominal tergite V; 72-74 - abdominal sternite VI; 75-77 — fore leg, trochanter and femur, anterior view; 78-80 — basal joint of urogomphi, dorsal view. Not to scale.

Рис. 66-80. Nodynus leucofasciatus, микроскульптура: 66, 69, 72, 75, 78 - личинка I возраста; 67, 70, 73, 76, 79 - II возраста; 68, 71, 74, 77, 80 - III возраста; 66-68 - мезонотум; 69-71 - V тергит брюшка; 72-74 - VI стернит брюшка; 75-77 — нога первой пары: вертлуг и бедро, спереди; 78-80 - базальный членик урогомфы, сверху. Не в масштабе.
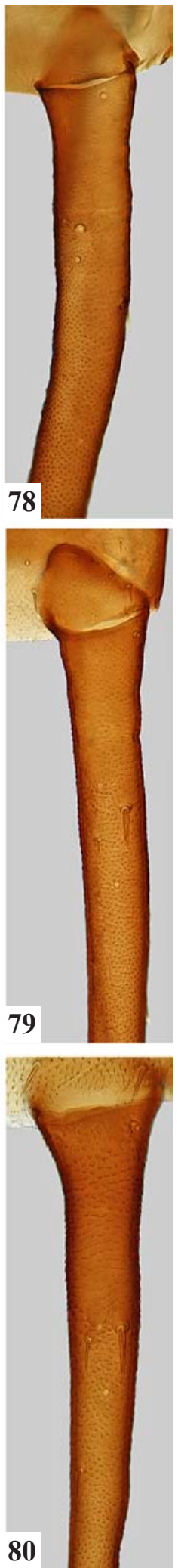
the development of extending laterotergites, mala with large galeal lobe covered in numerous setae and apically bilobed ligula were not found in both Nodynus and Apatetica larvae. So, based on larval morphology, we cannot confirm close relations of Apateticinae and Silphinae.

Sister-group of Trigonurinae or Scaphidiinae [Grebennikov, Newton, 2012; McKenna et al, 2015].

Most of the shared features of Apateticinae and Trigonurinae, such as six pairs of stemmata, shape of mandibles and epipharynx with multiporose structures couldn't indicate close relations, as was mentioned above. Although Grebennikov and Newton [2012] mentioned the presence of frayed setae on head and body segments of Trigonurus as shared feature with Apateticine larvae, judging by figures they are actually not frayed, but clavate pubescent ones [Pototskaya, 1976; Lawrence, 1991], which are very rare in Staphylinidae. Moreover, Trigonurus larva differs from Apateticinae by the bilobed ligula and epipleurites fused with abdominal tergites I-IX [Pototskaya, 1976]. Another inconsistent character is the number of urogomphi joints, which is two in Nodinus and Trigonurus, but single one in Apatetica (see remark above). Besides, urogomphal joints in Trigonurus have distinct ring-shaped sculpture [Grebennikov, Newton, 2012] which is absent in Apateticinae.

According to recent molecular phylogenetic studies, Apateticinae and Scaphidiinae considered to have a sister-group relations [McKenna et al, 2015; Gusarov, 2018]. Shared features of larvae of these two subfamilies are rather hard to point out because of variable morphology of Scaphidiinae, which larvae can have five or six pairs of stemmata, one- or two-jointed urogomphi, various shape of mandibles, etc. [Kasule, 1966; Kompantsev; 1987]. Nonetheless, larvae of these two subfamilies have both epicranial and tergal glands and the structure of thoracic endoskeleton is nearly identical in Scaphidium and Nodynus larvae. However, glands mentioned above are also found in Glypholomatinae, Aleocharinae, Oxytelinae and Staphylininae larvae [Kilian, 2007]. Identity of the thoracic endoskeleton potentially could be of taxonomic significance, but knowledge of its structure within Staphylinoidea is fragmentary, so this similarity should be treated with caution. Scaphidiinae larvae differ from Apateticinae by crenulate emargination on anterior margin of labrum, rounded ligula, epipleurites fused with abdominal tergites IIIX and hypopleurites fused with abdominal sternites VIII-IX [Ashe, 1984; Kompantsev, 1987]. Moreover, Scaphidiinae larvae lack frayed (and modified in general) setae and multiporose structures in epipharynx. So, in our opinion, there is no direct confirmation of close relations between Apateticinae and Scaphidiinae or Trigonurinae based on larval morphology.

Separate family in Staphylinoidea [Hansen, 1997]

Based even on preliminary comparative analysis given above, it becomes quite evident, that most morphological features of Apateticinae larvae (number of stemmata, shape of mandibles, presence of apically frayed setae and mutiporose structures, set of thoracic endoskeleton elements etc.), can be found in different combinations in various groups within the family. The only unique feature that can be established for Apateticinae is "tetra-lobed" ligula, so in our opinion there are not enough morphological evidences to count this group as separate family in Staphylinoidea. It is interesting to mention though, that very similar shape of ligula is known in some Hydraenidae [Deler-Hernández, Delgado, 2017], but it requires further elaboration.

At the present time it is rather difficult to make any conclusions about the taxonomic position of Apateticinae within the Staphylinidae (except that it's almost certain they are not part of Silphinae, which are often treated as staphylinid subfamily nowadays) due to combination of characters mentioned above in various representatives within the family. Thus, we preliminary agree with Grebennikov and Newton [2012], who refer this "basal" group as Staphylinidae incertae sedis.

\section{Notes on the chaetotaxy of Staphylinidae}

Nowadays two main nomenclatural systems of chaetotaxy are used in studies of various groups of Coleoptera. The first one is by Ashe and Watrous [1984], proposed initially for Aleocharinae and used later for other subfamilies of Staphylinidae, as well as, with certain degree of modification, different Staphyliniformia families, such as Leiodidae, Hydraeinidae, Catopidae, Ptiliidae [Wheeler, 1990; Delgado, Soler 1997; Sörensson, Delgado, 2019]. More recently this system was proposed for such distant groups as Helotidae and Monotomidae (Cucujoidea) [Lee et al, 2007; Wagner et al, 2020].

However, application of this system meets some difficulties in establishing of homologies within the family or Staphylinoidea in general. Firstly, in Ashe and Watrous paper chaetotaxy nomenclature for antennae, mandibles, and labio-maxillar complex have not been provided, although their setal pattern is rather constant within the family. Secondly, this system undergo various modifications in studies of other staphyliniform families, e.g. change in the setal rows orientation from transverse to longitudinal [Wheeler, 1990; Kilian, 2007] and different principle of coding [Delgado, Soler, 1997]. It resulted in the fact that obviously homological setae were coded differently, which could lead to confusion, especially when one tries to establish the common chaetome pattern for Staphyliniformia in general. For example, seta A12 [Ashe, Watrous, 1984] located on trochanter closely to pore $\mathrm{c} 4$, and typical for all Staphyliniformia (and most likely beetles in a whole), is coded as Ad1 for Leiodidae [Kilian, 2005] and Hydraenidae [Delgado, Soler, 1997]; frontal seta Fd3 in Aleocharinae is coded as Da2 for Leiodidae and Fd2 for Ptiliidae [Sörensson, Delgado, 2019], etc. So, despite significant number of homological setae in larvae of these families, this similarity is unobvious due to the different coding. Moreover, the designation of chaetome elements based on the location on certain side of the body or appendage (marginal, lateral, anterolateral, posteroventral, etc) could also become the reason of different names ap- 
pearing for the same setae. Such situation is rather natural, because the position of certain setae may change in comparison with Dalotia (Atheta) coriaria Kraatz, the model of Ashe' system, or even if orientation of the object on slide mount is different. In fact, it occurs even in studies within Aleocharinae, e.g., seta Pv1 on tibiotarsus may be coded as V1 [Staniec et al, 2018a] or Av2 [Staniec et al, 2018b]. All these difficulties resulted in the situation, when some authors rejected Ashe and Watrous system, suggesting consistent numeration of chaetome elements instead [Solodovnikov, Newton, 2005; Pietrykowska-Tudruj et al, 2011].

Also, Ashe and Watrous system is based on study of third-instar larvae, whose chaetotaxy is characterized by appearing of "secondary"setae, which number and position is significantly variable. Wheeler, in his study of Leiodidae [1990] pointed out the necessity of studying the chaetotaxy of first-instar larvae, and in subsequent works on Leiodidae, Hydraeinidae and other Staphyliniformia families [Delgado, Soler, 1997; Kilian, 1998] this was performed. Unfortunately, in most papers on larval chaetotaxy of Staphylinidae, data are provided only for lastinstar larvae, which makes certain difficulties in understanding common chaetome elements within the family.

The second nomenclatural system have been proposed by Bousquet and Goulet [1984] for Carabidae, and later improved by Makarov [1996]. It was subsequently used in studies of other adephagan families, such as Dytiscidae, Haliplidae, Rhysodidae [Alarie, Harper, 1990; Makarov, 2008; Michat et al, 2020], as well as Cupedidae (Archostemata) [Grebennikov, 2004], and Hydrophilidae (Hydrophiloidea) [Fikacek et al, 2008].

In our opinion this system have the following advantages over that of Ashe and Watrous: chaetotaxy of all the body regions and appendages was coded and the designation of homological setae carried out with the help of additional methods, such as sigillotaxy and diagnostic of rather stable complexes (e.g. "seta-pore") [Makarov, 1996].

Based on our study, it appears that significant part (about $70 \%$ ) of Nodynus chaetome elements can be reliably homologized with those of Carabidae (Table). The highest degree of congruence can be traced on body segments (except abdominal IX-X) and leg joints (except coxa). Less obvious homologies can be established for structures which undergo significant transformation comparing with Carabidae, such as labrum, labium, maxilla with galea and lacinia fused, as well as abdominal segment IX with two-jointed urogomphi. However, we believe that even on such structures more homological elements of chaetome could be found, if comprehensive study of first-instar staphylinid larvae would be performed. So, we conclude that Bousquet and Goulet system can be applied for Staphyliniformia larvae and, potentionally, other groups of beetles. It can be the first step to unified nomenclatural system of chaetotaxy for beetles larvae in general, based on homological elements, which can have a certain value for phylogenetic study within the order. Moreover, if we agree with the basal position of Apateticinae within Staphylinidae (see
Discussion above), it makes us suggest that their chaetome pattern can be close to original for the family, thus making it the "starting point" when analyzing other staphylinid larvae chaetotaxy.

Acknowledgements. We are sincerely grateful to K.V. Makarov (MPGU) for permission to use photo of adult Nodynus and for valuable comments during our study.

Competing interests. The authors declare no competing interests.

\section{References}

AlarieY., Harper P.P. Primary setae and pores on the last abdominal segment and the urogomphi of larval Hydroporinae (Coleoptera: Adephaga: Dytiscidae), with notes on other dytiscid larvae // Canadian Journal of Zoology. Vol.68. No.2. P.368-374. doi: 10.1139/z90-052.

Ashe J. 1984. Description of the larva and pupa of Scaphisoma terminataMelsh, and the larva of Scaphium castanipes Kirby with notes on their natural history (Coleoptera: Scaphidiidae) // The Coleopterists'bulletin. Vol.38. No.4. P.361-373.

Ashe J. 2005. Phylogeny of the tachyporine group subfamilies and 'basal' lineages of the Aleocharinae (Coleoptera: Staphylinidae) based on larval and adult characteristics // Systematic Entomology. Vol.30. No.1. P.3-37. doi: 10.1111/j.1365-3113.2004.00258.x.

Ashe J., Newton A. 1993. Larvae of Trichophya and phylogeny of the tachyporine group of subfamilies (Coleoptera: Staphylinidae) with a review, new species and characterization of the Trichophyinae // Systematic Entomology. Vol.18. P.267-286. doi: 10.1111/j.1365-3113.1993.tb00666.x.

Ashe J.S., Watrous L.E. 1984. Larval chaetotaxy of Aleocharinae (Staphylinidae) based on a description of Atheta coriaria Kraatz // Coleopterists Bulletin. Vol.38. P.165-179.

Bernhauer M., Schuber K. 1910. Staphylinidae I // Schenkling. Coleopterorum Catalogus. Berlin: Junk. Bd.5. H.19. S.1-86.

Bousquet Y., Goulet H. 1984. Notation of primary setae and pores on larvae of Carabidae (Coleoptera: Adephaga) // Canadian Journal of Zoology. Vol.62. No.4. P.573-588. doi: 10.1139/z84-085.

Böving A.G. 1921. The larvae and pupae of the social beetles Coccidotrophus socialis (Schwarz \& Barber) and Eunausibius wheeleri (Schwarz \& Barber) with remarks on the taxonomy of the family Cucujidae // Zoologica, New York. Vol.3. P.197-221.

Deler-Hernández A., Delgado J. A. 2017. The Hydraenidae of Cuba (Insecta: Coleoptera) II: Morphology of preimaginal stages of six species and notes on their biology // Zootaxa. Vol.4238. No.4. P. 451-498. doi: 10.11646/zootaxa.4238.4.1.

Delgado J.A., Soler A.G.1997. Morphology and chaetotaxy of larval Hydraenidae (Coleoptera) I: genus Limnebius Leach, 1815 based on a description of Limnebius cordobanus d'Orchymont // Aquatic Insects. Vol.19. No.1. P.37-49. doi: 10.1080/01650429709361634.

Dorsey C. 1940. A Comparative Study of the larvae of six species of Silpha (Coleoptera, Silphidae) // Annals of the Entomological Society of America. Vol.33. No.1. P.120-139. doi: 10.1093/ aesa/33.1.120.

Fauvel A. 1947. Staphylinides nouveaux de l'Inde et de la Malaisie // Revue d'Entomologie. Vol.14. No 6-7. P.180-220.

Fikacek M., Archangelsky M., Torres P. M. 2008. Primary chaetotaxy of the larval head capsule and head appendages of the Hydrophilidae (Insecta: Coleoptera) based on larvae of the genus Hydrobius Leach. // Zootaxa. Vol.1874. P.16-34. doi: 10.11646/zootaxa.1874.1.2.

Fukuda A. 1959. Illustrated insect larvae of Japan. (Ed. Kawada). Tokyo: Hokuryukan. 420 pp.

Grebennikov V. 2004. Review of larval morphology of beetles of the suborder Archostemata (Insecta: Coleoptera), including firstinstar chaetotaxy // European Journal of Entomology. Vol.101. P.273-292.doi: 10.14411/eje.2004.038.

Grebennikov V.V., Newton A.F. 2012. Detecting the basal dichotomies in the monophylum of carrion and rove beetles (Insecta: Coleoptera: Silphidae and Staphylinidae) with emphasis on the 
Oxyteline group of subfamilies // Arthropod Systematics \& Phylogeny. Vol.70. No.3. P. 133-165.

Gusarov V. 2018. Phylogeny of the family Staphylinidae based on molecular data: a review // Betz O., Irmler U., Klimaszewski J. (eds.). Biology of rove beetles (Staphylinidae). Life history, evolution, ecology and distribution. Springer. P.7-25. doi: $10.1007 / 978-3-319-70257-5 \quad 2$.

Hansen M. 1997a. Phylogeny and classification of the staphyliniform beetle families (Coleoptera) // Biologiske Skrifter, Det Kongelige Danske Videnskabernes Selskab. Vol.48. P.1-339. doi: 10.1076/0165-0424(200006)22:3;1-I;FT242.

Jansson A. 1947. Entomological results from the Swedish expedition 1934 to Burma and British India. Coleoptera: Staphylinidae et Silphidae collected by Rone Malaise // Arkiv for Zoologi. Vol.38A. No.19.

Kasule F.K. 1966. The subfamilies of the larvae of Staphylinidae (Coleoptera) with keys to the larvae of the British genera of Steninae and Proteininae // Transactions of the Royal Entomological Society of London. No.118. P.261-283. doi: 10.1111/ j.1365-2311.1966.tb00838.x.

Kilian A.1998. Morphology and phylogeny of the larval stages of the tribe Agathidini (Coleoptera: Leiodidae: Leiodinae) // Annales Zoologici. Vol.48. Nos3-4. P.125-220.

Kilian A. 2005. Studies on the morphology of immature stages of the tribe Agathidiini (Coleoptera: Leiodidae). Part II. Anisotoma blanchardi // European Journal of Entomology. Vol.102. P.97105. doi:10.14411/eje.2005.014

Kilian A. 2007. Comparative morphology of larval Camiarinae (Coleoptera: Leiodidae) Part I. Genus Paragyrtodes Szymczakowsk 1966//Zootaxa. Vol.1640. No.1. doi: 10.11646/zootaxa.1640.1.1.

Kobayashi Y e et al. 2013. Embryonic development of Carabus insulicola (Insecta, Coleoptera, Carabidae) with special reference to external morphology and tangible evidence for the subcoxal theory // Journal of morphology. Vol.274. No.13. P.1323-1352. doi: 10.1002/jmor.20181.

Kompantsev A.V., Pototskaya V.A. 1987. [Novye dannye po lichikam zhukov-chelnovidok (Coleoptera, Scaphidiidae)]// Pravdin F.N. (ed.). Ekologiya i morfologiya nasekomych-obyvateley gribnych substratov. Moscow: Nauka. P.87-100 [in Russian].

Kovarik P.W., Passoa S. 1993. Chaetotaxy of Larval Histeridae (Coleoptera: Hydrophiloidea) Based on a Description of Onthophilus nodatus LeConte // Annals of the Entomological Society of America. Vol.86. No.5. P.560-576. doi: 10.1093/aesa/86.5.560

Lawrence J.F. 1991. Order Coleoptera (general discussion, family key, 88 family treatments) // Stehr F.W. (ed.). Immature Insects. Vol.2. Dubuque, Iowa: Kendall/Hunt Publishing Co. P.144-658.

Lawrence J.F., Newton A.F. 1995. Families and subfamilies of Coleoptera (with selected genera, notes, references and data on family-group names) // Pakaluk J., Slipinski S.A. (eds.). Biology, Phylogeny, and Classification of Coleoptera. Warszawa. P.779-1006.

Lee C-F., Hisamatsu S., Yang P.-S. 2007. Morphology and ontogeny of immature stages of Helotidae based on descriptions of Helota thoracica Ritsema and $\mathrm{H}$. gemmata Gorham (Insecta: Coleoptera: Cucujoidea) // Zoological studies. Vol.46. P.760-769.

Madge R.B. 1979. Taxonomic notes on Apatetica Westwood (Coleoptera: Silphidae), with a review of the species with black elytra / Oriental Insects. Vol.13. No.3-4. P.311-321.doi: 10.1080/ 00305316.1979.10433624.

Makarov K.V. 1996. Patterns of chaetome modifications in groundbeetle larvae (Coleoptera: Carabidae) // Acta Societatis ZoologicaeBohemicae. Vol.60. P.391-418.

Makarov K.V. 2008. Larval chaetotaxy in the genus Rhysodes Dalman, 1823 and the position of Rhysodidae within Adephaga // Penev L. Erwin T., AssmannT. (eds.). Back to the Roots and Back to the Future. Towards a New Synthesis amongst Taxonomic, Ecological and Biogeographical Approaches in Carabidology Proceedings of the XIII European Carabidologists Meeting, Blagoevgrad, August 20-24, 2007. Sofia, Moscow: Pensoft. P.101-123.

McKenna D.D. et al. 2015. The beetle tree of life reveals that Coleoptera survived end-Permian mass extinction to diversify during the Cretaceous terrestrial revolution // Systematic Entomology. Vol.40. P.835-880. doi: 10.1111/syen.12132.
Michat M., Archangelsky M., Alarie Y. 2020. Morphology and chaetotaxy of Neotropical Haliplus larvae (Coleoptera: Haliplidae) // Revista Mexicana de Biodiversidad. Vol.91. P.1-12.doi: 10.22201/ib.20078706e.2020.91.3541.

Newton A. F. 1982a. Redefinition, revised phylogeny, and relationships of Pseudopsinae (Coleoptera, Staphylinidae) // Amer. Mus. Novit. No.2743. P.1-13.

Newton A.F., Thayer M.K. 1992. Current Classification and FamilyGroup Names in Staphyliniformia (Coleoptera) // Fieldiana: Zoology. New Series. No.67.P.1-92. doi: 10.5962/bhl.title.3544.

Newton A. 2018. Staphyliniformia world catalog database // O. Bánki, Y. Roskov, L. Vandepitte, R. E. DeWalt, D. Remsen, P. Schalk, T. Orrell, M. Keping, J. Miller, R. Aalbu, R. Adlard, E. Adriaenssens, C. Aedo, E. Aescht, N. Akkari, M. A. Alonso-Zarazaga, B. Alvarez, F. Alvarez, G. Anderson et al. Catalogue of Life Checklist (Nov 2018). https://doi.org/10.48580/d4sl-3gk.

Pietrykowska-Tudruj E., Staniec B., Solodovnikov A. 2011. Discovery of the Quedius antipodum Sharp larva from New Zealand: phylogenetic test of larval morphology for Staphylinini at the intratribal level (Coleoptera: Staphylinidae) // Systematic Entomology. Vol.37. P.360-378. doi: 10.1111/j.1365-3113.2011.00612.x.

Pototskaya V.A. 1976. [Morphology of Trigonurus asiaticusReiche larva and relation of the tribe Trigonurini with other tribes of the subfamily Piestinae (Coleoptera, Staphylinidae)] // Mamaev B.M. (ed.). Evoliutsionnaia morfologiia lichinok nasekomykh. Moscow: Nauka. P.13-21 [in Russian].

Shavrin A.V. 2008. Apateticinae Fauvel, 1895 is a new for the Russia subfamily of the rove beetles (Coleoptera, Staphylinidae) // Far Eastern Entomologist. No.187. P.12.

Solodovnikov A.Yu., Newton A.F. 2005. Phylogenetic placement of Arrowinini trib. $n$. within the subfamily Staphylininae (Coleoptera: Staphylinidae), with revision of the relict South African genus Arrowinus and description of its larva // Systematic Entomology. Vol.30. P.398-441. doi: 10.1111/j.1365-3113.2004.00283.x.

Staniec B., Pietrykowska-Tudruj E. 2011. A description of the mature larva of Philonthus lepidus (Gravenhorst, 1802) - a stenotopic species of rove-beetle // Polish Journal of Entomology. Vol.80. P.33-46.doi: 10.2478/v10200-011-0004-5.

Staniec B., Pietrykowska-Tudruj E., Pawlêga K. 2018. First description of the larva of Dinaraea Thomson, 1858, with comments on chaetotaxy, pupa, and life history based on two saproxylic species from Europe (Staphylinidae, Aleocharinae, Athetini) // ZooKeys. Vol.752. P.99-123.doi:10.3897/zookeys.752.24440.

Staniec B., Zagaja M., Pietrykowska-Tudruj E., Wagner G. K. 2018. Comparative larval ultramorphology of some myrmecophilous Aleocharinae (Coleoptera, Staphylinidae), with a first description of the larvae of Amidobia talpa (Heer O, 1841) and Oxypoda haemorrhoa (Mannerheim C.G., 1830), associated with the Formica rufa species group // ZooKeys. Vol.808. P.93-114.

Steel W. 1970. The larvae of the genera of the Omaliinae (Coleoptera: Staphylinidae) with particular reference to the British fauna // Transactions of the Royal Entomological Society of London. Vol.122. P.1-47. doi: 10.1111/j.1365-2311.1970.tb00524.x.

Thayer M. 2005. Staphylinoidea // Beutel R.G., Leschen R.A.B. (eds.). Handbook of Zoology. Vol. IV. Arthropoda: Insecta. Part 38. Coleoptera. Vol.1. Morphology and Systematics (Archostemata, Adephaga, Myxophaga, Polyphagapartim). Berlin, New York: De Gruyter. P.296-344. doi: 10.1515/9783110904550.

Wagner G., Staniec B., Zagaja M., Pietrykowska-Tudruj E. 2020. First insight into detailed morphology of monotomids, with comments on chaetotaxy and life history based on myrmecophilous Monotoma angusticollis // Bulletin of Insectology. Vol.73. P.11-27.

WaterhouseC.O.1876. On various new genera and species of Coleoptera // Transactions of the Entomological Society of London. 1876. P.11-25.

Westwood J.O. 1848. The cabinet of Oriental entomology, being a selection of some of the rarer and more beautiful species of insects, natives of India and the adjacent islands, the greater portion of which are now for the first time described and figured. London: W. Smith. 88 pp., 42 pls.

Wheeler Q.D. 1990. Morphology and ontogeny of postembryonic larval Agathidium and Anisotoma (Coleoptera: Leiodidae) // Amer. Mus. Novit. Nol.2986. P.1-46. 
Table. Setal and pore homologs found in staphylinid and carabid larvae. Таблица. Хеты и поры, гомологичные для личинок стафилинов и жужелиц.

\begin{tabular}{|c|c|c|c|}
\hline \multicolumn{2}{|r|}{ Body region } & Ashe, Watrous [1984] & Bousquet, Goulet [1984] \\
\hline \multirow{7}{*}{ Head } & Frontal sclerite & $\begin{array}{l}\text { Fd1, Fd2, Fd3 } \\
\text { Fm1 } \\
\text { Fl1, Fl2, Fl3, } \\
\text { Fc1, Fc2 }\end{array}$ & $\begin{array}{l}\text { FR5, FR4, FR3 } \\
\text { FR6 } \\
\text { *FR7, FR1, FR2 } \\
\text { *FRc/e, FRb }\end{array}$ \\
\hline & Labrum & $\begin{array}{l}\text { Ld1 } \\
\text { Lm1, Lm2 } \\
\text { L11 }\end{array}$ & $\begin{array}{l}\text { *FR11 } \\
\text { *FR10, *FR9 } \\
\text { *FR8 }\end{array}$ \\
\hline & Parietal sclerite & $\begin{array}{l}\text { P2, P3, P4 } \\
\text { Ed1, Ed2, Ed3 } \\
\text { El1, El3 } \\
\text { Em2 } \\
\text { V1 } \\
\text { V11 } \\
\text { Ec1, Ec2, Ec3 } \\
\text { Vc1, Vc2 }\end{array}$ & $\begin{array}{l}\text { PA3, PA2, PA1 } \\
\text { PA7, PA5, PA4 } \\
\text { PA10, PA6 } \\
\text { PA9 } \\
\text { *PA17 } \\
\text { *PA12 } \\
\text { PAd, PAb, PAa } \\
\text { *PAn, *PAi }\end{array}$ \\
\hline & Antenna & not coded* & $\begin{array}{l}\text { AN1, AN2, AN3, AN4, AN5, AN6, AN7 } \\
\text { ANa, ANb, }{ }^{*} \text { ANc/d, }{ }^{*} \text { ANd/e, ANf }\end{array}$ \\
\hline & Mandible & not coded & $\begin{array}{l}\text { MN1 } \\
\text { MNa, MNb }\end{array}$ \\
\hline & Maxilla & not coded & $\begin{array}{l}\text { MX1, MX2, MX3, }{ }^{*} \text { MX9, MX10, MX11, } \\
\text { MX12 } \\
\text { MXe, MXf, MXg }\end{array}$ \\
\hline & Labium & not coded & $\begin{array}{l}\text { PA16, PA18, PA19 } \\
\text { LA1, LA2, LA6 } \\
\text { PAo, LAa, LAb, LAc }\end{array}$ \\
\hline \multirow{9}{*}{ Thorax } & Pronotum & $\begin{array}{l}\mathrm{A1}, \mathrm{A2}, \mathrm{A3}, \mathrm{A5} \\
\mathrm{L} 1, \mathrm{~L} 2, \mathrm{L4} \\
\mathrm{Da} 2, \mathrm{Dc} 2, \mathrm{Dd} 2 \\
\text { P1, P2, P3, P4,P5 } \\
\text { C1, C2, C', C", C3, C4, C5, } \\
\text { C6 }\end{array}$ & $\begin{array}{l}\text { PR1, PR2, PR3, PR4 } \\
\text { PR5, PR6, PR9 } \\
\text { PR14, PR8, PR7 } \\
\text { PR13, PR12,PR } \alpha \text {, PR11, PR10 } \\
\text { PRb, PRc, PRd, PRe, PRh, PRi, PRk, PRI }\end{array}$ \\
\hline & Mesonotum & \begin{tabular}{|l} 
A1, A2, A3, A4, A5 \\
L1, L3, L4 \\
P1, P2,P3,P4 \\
Da2, Db1, Db2 \\
C1, C3,C4,C6, C
\end{tabular} & $\begin{array}{l}\text { ME4, ME3, ME5, ME6, ME7 } \\
\text { ME9, ME10, ME11 } \\
\text { ME14, ME13,MEd, ME12 } \\
\text { ME1, ME2, ME8 } \\
\text { PRa, PRd, PRb, PRg, PRe }\end{array}$ \\
\hline & \begin{tabular}{|l|} 
Cervicosternum \\
\end{tabular} & Pr1, Pr2, Eu1, Eu2 & gPS \\
\hline & Episternite I & Prehy',Prehy1, Prehy2, Ls2 & ES1, ES2, ES3, ES4 \\
\hline & Epimerite I-III & Pohy1 & EM1 \\
\hline & Prosternite & St1, St2 & PS1, PS2 \\
\hline & Episternite II-III & not coded & ES1, ES5, ES6 \\
\hline & Meso-, metasternite & not coded & MS1, MS2, MS3, MS4 \\
\hline & Pleurite II-III & not coded & PL1 \\
\hline \multirow{5}{*}{ Leg } & Coxa & \begin{tabular}{|l|} 
Bs1, Bs2, Bs3 \\
Ad2, Ad1, Pd1 \\
C1, C2
\end{tabular} & $\begin{array}{l}\mathrm{CO} 1, \mathrm{CO} 2, \mathrm{CO} 3 \\
\mathrm{CO}, \mathrm{CO} 10, \mathrm{CO} 11 \\
\mathrm{COb}, \mathrm{COa}\end{array}$ \\
\hline & Trochanter, anterior & $\begin{array}{l}\text { Al2, Av1, Av2 } \\
\text { C1, C2, C3, C4, C5 }\end{array}$ & \begin{tabular}{|l|} 
TR1, TR3, TR2 \\
TRe, TRd, TRe, TRb, TRa
\end{tabular} \\
\hline & Trochanter, posterior & $\begin{array}{l}\text { Pl1, Pv1, Pv2 } \\
\text { C6, C7 }\end{array}$ & $\begin{array}{l}\text { TR6, TR5, TR7 } \\
\text { TRf, TRg }\end{array}$ \\
\hline & Trochanter, ventral & V1 & TR4 \\
\hline & Femur, dorsal & $\begin{array}{l}\text { D1 } \\
\text { C1 }\end{array}$ & $\begin{array}{l}\text { FE1 } \\
\text { FEa }\end{array}$ \\
\hline
\end{tabular}


Table. Ending

Таблица. Окончание.

\begin{tabular}{|c|c|c|c|}
\hline \multicolumn{2}{|c|}{ Body region } & Ashe, Watrous [1984] & Bousquet, Goulet [1984] \\
\hline \multirow{5}{*}{ Leg } & Femur, anterior & $\begin{array}{l}\text { Ad1, Av1, Av2 } \\
\text { C2 }\end{array}$ & $\begin{array}{l}\text { FE2, FE6, FE3 } \\
\text { FEb }\end{array}$ \\
\hline & Femur, posterior & Pd1, Pv1 & FE5, FE4 \\
\hline & Tibiotarsus, anterior & $\begin{array}{l}\text { Ad1, Ad2, Ad3, Av1, Av2 } \\
\text { C1, C2 }\end{array}$ & $\begin{array}{l}\text { TA2, TA1, TI2, TI4, TI3 } \\
\text { TAb, TAa }\end{array}$ \\
\hline & Tibiotarsus, posterior & Pd1, Pd2, Pl1, Pv1 & TA7, TI7, TI6, TI5 \\
\hline & Pretarsus & not coded & UN1, UN2 \\
\hline \multirow{6}{*}{ Abdomen } & $\begin{array}{l}\text { Tergite I-VIII } \\
\text { (+epipleurite I-III) }\end{array}$ & $\begin{array}{l}\text { A2, A4, A5 } \\
\text { P1,P2,P3, P4, P5 } \\
\text { Da2, Db2, Dd2 } \\
\text { L1, L4, L5 } \\
\text { C1, C5, C6 }\end{array}$ & $\begin{array}{l}\text { TE2, TE3, TE4 } \\
\text { TE11, TE10, TE } \alpha, \text { TE } \beta, \text { TE9 } \\
\text { TE1, TE6, TE7 } \\
\text { EP1, EP2, TE8 } \\
\text { TEa, TEc, TEd }\end{array}$ \\
\hline & $\begin{array}{l}\text { Tergite IX and } \\
\text { urogomphi }\end{array}$ & $\begin{array}{l}\text { A2, L1, P5 } \\
\text { Ud1, Ud', Ud4, Uv2 } \\
\text { not coded }\end{array}$ & $\begin{array}{l}\text { UR1, UR2, UR3 } \\
\text { UR4, UR5, UR8, UR9 } \\
\text { URa, URd }\end{array}$ \\
\hline & Sternite I & Ps1, P1, P2,D2 & ST1, ST3, ST4, ST2 \\
\hline & $\begin{array}{l}\text { Sternite II-VIII } \\
\text { (+hypopleurite II) }\end{array}$ & Ps1, P1, P2, P4, P5, P6, D2 & ST1, ST3, ST4, ST5, HY1, HY2, ST2 \\
\hline & Sternite IX & Ps1, P1, P2, P4 & ST1, ST3, ST4, ST5 \\
\hline & Pygopod & not coded & $\begin{array}{l}\text { PY1, PY2, PY3, PY6, PY7 } \\
\text { PYa, PYf }\end{array}$ \\
\hline
\end{tabular}

NOTE. Reliable homologies typed in bold. Setae and pores, lacking in Dalotia (Atheta) coriaria, but common in Nodynus and Carabidae coded with '. * Although chaetotaxy of these structures not coded in Ashe and Watrous [1984] system, homology can be established.

ПРИМЕЧАНИЕ. Надёжные гомологии выделены жирным шрифтом. Хеты и поры, не указанные для Dalotia (Atheta) coriaria, но общие у Nodynus и Carabidae, обозначены c '. * Хотя номенклатура хетотаксии этих структур не приводится в системе Аshe и Watrous [1984], гомологичные элементы могут быть установлены. 